\title{
Growth Factor Treatment and Genetic Manipulation Stimulate Neurogenesis and Oligodendrogenesis by Endogenous Neural Progenitors in the Injured Adult Spinal Cord
}

\author{
Yasuo Ohori, ${ }^{1,3,4}$ Shin-ichi Yamamoto, ${ }^{3,4}$ Motoshi Nagao, ${ }^{1}$ Michiya Sugimori, ${ }^{1}$ Naoya Yamamoto, ${ }^{4}$ Kozo Nakamura, ${ }^{3}$ and \\ Masato Nakafuku $u^{1,2,5}$ \\ ${ }^{1}$ Division of Developmental Biology, Cincinnati Children's Hospital Research Foundation, Cincinnati, Ohio 45229-3039, ${ }^{2}$ Departments of Pediatrics and \\ Neurosurgery, University of Cincinnati College of Medicine, Cincinnati, Ohio 45267-0521, ${ }^{3}$ Department of Orthopaedic Surgery, The University of Tokyo \\ Graduate School of Medicine, Bunkyo-ku, Tokyo 113-0033, Japan, ${ }^{4}$ Division of Motor Dysfunction, Research Institute, National Rehabilitation Center, \\ Tokorozawa, Saitama 359-8555, Japan, and ${ }^{5}$ Solution Oriented Research for Science and Technology, Japan Science and Technology Agency, Chuo-ku, \\ Tokyo 103-0027, Japan
}

Neurons and oligodendrocytes are highly vulnerable to various insults, and their spontaneous replacement occurs to only a limited extent after damage in the adult spinal cord. The environment of injured tissue is thus thought to restrict the regenerative capacity of endogenous neural stem/progenitor cells; strategies for overcoming such restrictions remain to be developed. Here, we combined growth factor treatment and genetic manipulation to stimulate neurogenesis and oligodendrogenesis by endogenous progenitors in vivo. The recombinant retrovirus PMXIG, which was designed to coexpress green fluorescent proteins (GFPs) and a neurogenic/gliogenic transcription factor, was directly injected into the injured spinal cord parenchyma to manipulate proliferative cells in situ. We found that cells expressing 0lig2, Nkx2.2, and NG2 were enriched among virus-infected, GFP-positive $\left(\mathrm{GFP}^{+}\right)$cells. Moreover, a fraction of GFP ${ }^{+}$cells formed neurospheres and differentiated into neurons, astrocytes, and oligodendrocytes in vitro, demonstrating that GFP retroviruses indeed infected endogenous neural progenitors in vivo. Neuronal differentiation of control virus-infected cells did not occur at a detectable level in the injured spinal cord. We found, however, that direct administration of fibroblast growth factor 2 and epidermal growth factor into lesioned tissue could induce a significant fraction of GFP-labeled cells to express immature neuronal markers. Moreover, retrovirus-mediated overexpression of the basic helix-loop-helix transcription factors Neurogenin2 and Mash1, together with growth factor treatment, enhanced the production and maturation of new neurons and oligodendrocytes, respectively. These results demonstrate that endogenous neural progenitors can be manipulated to replace neurons and oligodendrocytes lost to insults in the injured spinal cord.

Key words: stem cell; regeneration; repair; spinal cord injury; neurogenesis; oligodendrocyte; bHLH factor; growth factor

\section{Introduction}

The adult mammalian CNS is highly vulnerable to various insults. It has long been thought that such vulnerability is attributable to the lack of cell sources for replacing dead and/or damaged

Received Jan. 11, 2006; revised Sept. 5, 2006; accepted 0ct. 10, 2006.

This work was supported in part by the Ohio Eminent Scholar Award of the Sate of Ohio, the Solution Oriented Research for Science and Technology Program, Japan Science and Technology Agency, and grants-in-aids from The Ministry of Education, Culture, Sports, Science and Technology, Japan. We thank Drs. T. Kitamura, K. Miyazono, Y. Gotoh, Y. Ihara, and I. Dobashi for reagents and technical assistance. We also thank Drs. C. Wylie, T. Boat, A. Seichi, S. Tanaka, Y. Tajiri, T. Miura, and T. Ogata, and the members of our laboratories for encouragement and support. We declare that the authors of this study have no financial conflicts of interest that might be construed to influence the results or interpretation of this study.

Correspondence should be addressed to Dr. Masato Nakafuku, Division of Developmental Biology, Cincinnati Children's Hospital Research Foundation, 3333 Burnet Avenue, Cincinnati, $\mathrm{OH}$ 45229-3039. E-mail: masato.nakafuku@cchmc.org.

DOI:10.1523/JNEUROSCI.3127-06.2006

Copyright $\odot 2006$ Society for Neuroscience $\quad$ 0270-6474/06/2611948-13\$15.00/0 cells (Horner and Gage, 2000). Many lines of previous studies, however, have revealed that neural stem and other progenitor cells [herein collectively called neural progenitor cells (NPCs)] persist in the adult CNS (Q. Cao et al., 2002). In fact, neurogenesis and gliogenesis continue in some regions of the adult brain in various species, including humans (Goldman, 2004).

Such continuous cell genesis, however, is confined to only a few areas under physiological conditions, and moreover, regeneration of new cells appears to be very limited even after damage in most regions of the CNS (Goldman, 2004). In particular, the adult spinal cord has been considered to be one of the most restrictive regions in which NPCs can contribute to cell replacement after injury (Q. Cao et al., 2002; Dobkin and Havton, 2004). Previous cell culture studies have demonstrated that the adult spinal cord contains an abundant source of endogenous NPCs (Weiss et al., 1996; Johansson et al., 1999; Shihabuddin et al., 
2000; Yamamoto et al., 2001a; Martens et al., 2002). Nevertheless, production of new neurons and oligodendrocytes by such endogenous cells occurs to only a very limited extent after injury in vivo (McTigue et al., 1998, 2001; Johansson et al., 1999; Yamamoto et al., 2001a,b; Kojima and Tator, 2002; Zai and Wrathall, 2005; Horky et al., 2006; Yang et al., 2006). Furthermore, cell transplantation studies have demonstrated that exogenous NPCs, which retain strong neurogenic and/or oligodendrogenic activities in vitro, differentiate only very poorly when grafted into the spinal cord (Chow et al., 2000; Shihabuddin et al., 2000; Q. L. Cao et al., 2001, 2002; Han et al., 2002, 2004; Hill et al., 2004; Enzmann et al., 2005). Thus, the environment of the spinal cord appears to be highly restrictive for differentiation of NPCs. If this environmental restriction can be relieved by certain manipulations, endogenous NPCs may be able to supply new neurons and oligodendrocytes, which in turn may contribute to the reconstruction of local circuitry and facilitate regeneration of long-distance axonal tracts (Schwab, 2002; Dobkin and Havton, 2004). However, such strategies to manipulate endogenous NPCs remain unexplored to date.

In this study, we tested two strategies to manipulate neuronal and glial differentiation of endogenous NPCs in vivo. The first was direct administration of a mixture of growth factors (GFs), fibroblast growth factor 2 (FGF2) and epidermal growth factor (EGF), into injured tissue and the second was virus-mediated overexpression of the transcription factors Neurogenin2 (Ngn2) and Mash1. We show that the combination of these manipulations can stimulate the production of new neurons and oligodendrocytes by endogenous NPCs in the injured spinal cord.

\section{Materials and Methods}

Spinal cord injury. Young adult Sprague Dawley rats (7-9 weeks of age and weighing $250-330 \mathrm{~g}$ ) were used in all experiments. All experimental procedures were performed according to the guidelines of the Institutional Animal Care and Use Committee and National Institutes of Health. Rats were anesthetized with $50 \mathrm{mg}$ of ketamine $\mathrm{HCl}$ and $5 \mathrm{mg}$ of xylazine (100 and $20 \mathrm{mg} / \mathrm{ml}$, respectively; Phoenix Pharmaceuticals, St. Joseph, MO) per kilogram of body weight. Laminectomy and complete transection of the spinal cord at the tenth thoracic (T10) level were performed as described previously (Yamamoto et al., 2001a,b).

Growth factor treatment and retrovirus infection in vivo. Recombinant retroviruses pMXIG and pMXIG-Ngn2, which are designed to express green fluorescent protein (GFP) as a marker for infected cells, were described previously (Morita et al., 2000; Yamamoto et al., 2001b). pMXIG-Mash1 was constructed by inserting the full-length cDNA for rat Mash1 (Torii et al., 1999) into the pMXIG vector. For virus infection in vivo, a $30 \mu \mathrm{l}$ solution of artificial CSF (aCSF) containing high-titer retroviruses $\left(2 \times 10^{8}\right.$ colony-forming unit $\left./ \mathrm{ml}\right), 0.1 \mathrm{mg} / \mathrm{ml} \mathrm{rat} \mathrm{serum} \mathrm{albu-}$ min (Sigma, St. Louis, MO), and $4 \mu \mathrm{g} / \mathrm{ml}$ polybrene (Sigma) was injected manually into three different locations $(10 \mu \mathrm{l}$ each) of the transected spinal cord parenchyma using Hamilton syringes (Hamilton, Reno, NV). In some experiments, recombinant human FGF2 ( $1 \mu \mathrm{g}$; Peprotech, Rocky Hill, NJ), mouse EGF ( $1 \mu \mathrm{g}$; Roche, Indianapolis, IN), and human brain-derived neurotrophic factor (BDNF) ( $2 \mu \mathrm{g}$; Sigma) were premixed and coinjected with retroviruses. An equivalent amount of rat serum albumin was used as control. To label proliferating cells, 5-bromo2 ' deoxyuridine (BrdU) (150 mg/kg of body weight; Sigma) dissolved in $0.9 \%$ sterile saline was injected intraperitoneally twice a day for $3 \mathrm{~d}$ between day after injury 0 (DAI0) and DAI2. The first administration of BrdU was performed immediately after virus injection, and subsequently repeated every $12 \mathrm{~h}$.

In vitro culture. Spinal cord stumps $\sim 4 \mathrm{~mm}$-long both rostral and caudal from the lesion epicenter were subjected to in vitro culture as described previously (Yamamoto et al., 2001a,b) with some modifications. In brief, the harvested tissue was cut into small pieces in ice-cold aCSF containing the following (in $\mathrm{mm}$ ): $124 \mathrm{NaCl}, 5 \mathrm{KCl}, 1.3 \mathrm{MgCl}_{2}, 2$
$\mathrm{CaCl}_{2}, 26 \mathrm{NaHCO}_{3}$, and 10 D-glucose. Subsequently, the tissue was dissociated by incubation with $0.1 \%$ (w/v) trypsin (Sigma), $0.67 \mathrm{mg} / \mathrm{ml}$ hyaluronidase (Sigma), and $0.1 \mathrm{mg} / \mathrm{ml}$ deoxyribonuclease I (Roche) in aCSF at $37^{\circ} \mathrm{C}$ for $30 \mathrm{~min}$, with aeration with $95 \% \mathrm{O}_{2} / 5 \% \mathrm{CO}_{2}$. Trypsin was neutralized with $0.7 \mathrm{mg} / \mathrm{ml}$ ovamucoid (Sigma) and the resultant tissue suspension was triturated mechanically to yield a single cell suspension. In some experiments, the resultant cells were immediately seeded onto poly-D-lysine (PDL; $100 \mu \mathrm{g} / \mathrm{ml}$; Sigma)-coated eight-well chambers (Nalge Nunc International, Rochester, NY) and subjected to immunostaining $2 \mathrm{~h}$ after plating.

To initiate neurosphere culture, fragmented neuropiles and other debris were removed from the above-described dissociated single cell suspension by filtration through serum cushion and a sterile nylon mesh (40 $\mu \mathrm{m}$ pore diameter; Becton, Dickinson and Company, Franklin Lakes, NJ) (Yamamoto et al., 2001b). The resultant single cells were seeded at the density of $2 \times 10^{4}$ cells/ml in a growth medium [1:1 mixture of DMEM and F-12 medium supplemented with B-27 and N2 culture supplements (Invitrogen, Carlsbad, CA), $20 \mathrm{ng} / \mathrm{ml}$ bovine FGF2, $20 \mathrm{ng} / \mathrm{ml}$ mouse EGF, $20 \mathrm{ng} / \mathrm{ml}$ human platelet-derived growth factor (R \& D Systems, Minneapolis, MN), $2 \mu \mathrm{g} / \mathrm{ml}$ heparin (molecular mass 3000; Sigma), $1 \mathrm{mg} / \mathrm{ml}$ bovine serum albumin (Sigma), and $100 \mu \mathrm{M}$ 2-mercaptoethanol (Sigma)]. Culture dishes were coated with poly [2-hydroxyethyl methacrylate] (Sigma) to prevent cell attachment (Yamamoto et al., 2001b). At day 14 in vitro (DIV14), forming floating neurospheres were collected and subjected to either serial passages under the same condition or differentiation culture. Under these conditions, $0.9 \pm 0.1 \%$ ( $n=6$ independent experiments) of initially seeded viable cells formed neurospheres, and this frequency was maintained in subsequent four passages.

To induce differentiation into neurons and glia, neurospheres grown in the presence of GFs were seeded onto PDL-coated eight-well chambers, either as cell aggregates or dissociated single cells, at a density of $2 \times$ $10^{4}$ cells per well, and subsequently cultured in the above medium without GFs or heparin for $6 \mathrm{~d}$. In some experiments, the following peptide factors were added to the culture medium: human bone morphogenetic protein 4 (BMP4; $10 \mathrm{ng} / \mathrm{ml}$; R \& D systems), mouse noggin (100 ng/ml; R \& D Systems), human ciliary neurotrophic factor $(\mathrm{CNTF} ; 50 \mathrm{ng} / \mathrm{ml}$; Sigma), and human BDNF (50 ng/ml; Sigma). To count cell numbers, cell nuclei were stained with $1 \mu \mathrm{g} / \mathrm{ml} 4^{\prime}$,6-diamidino-2-phenylindole (DAPI; Invitrogen).

Retrovirus infection in vitro. The full-length cDNAs for mouse Smad6 and Samd7, and a dominant-negative form of mouse STAT3 (Kamakura et al., 2004) were kind gift from Drs. K Miyazono and Y. Gotoh (The University of Tokyo, Tokyo, Japan), respectively, and cloned into pMXIG vector. Primary neurospheres collected at DIV14 were subjected to virus infection as described previously (Yamamoto et al., 2001b). Infected cells were maintained in floating culture for a week, during which $\sim 10 \%$ of the cells expressed GFP. The resultant secondary neurospheres were dissociated, seeded onto PDL-coated chambers, and incubated for additional $2 \mathrm{~d}$ without GFs to induce differentiation.

Immunostaining. Affinity-purified rabbit polyclonal antibodies (pAbs) against nestin (diluted 1:1000), Olig2 (1:2000), Ngn2 (1:5000), and Sox 2 (1:1000) were described previously (Yamamoto et al., 2001a,b). Rabbit antibody for microtubule-associated protein 2 (MAP2) (react with c subunit, 1:4000) was generous gift from Dr. Y. Ihara (The University of Tokyo) (Yamamoto et al., 2001b). Mouse monoclonal antibodies (mAbs) against nestin (Rat401, 1:500), Nkx2.2 (74.5A5, 1:1000), HB9 (81.5C10, 1:50), Islet1 (39.4D5, 1:50), Lim1 (4F2, 1:50), Lim3 (67.4E12, 1:50), and RIP (Rip, 1:100) were obtained from the Developmental Studies Hybridoma Bank of the University of Iowa. Other antibodies were purchased from commercial sources: GFP [mouse mAb, 1:500; rabbit pAb, 1:5000 (Invitrogen); and rat mAb, 1:5000 (Nacalai Tesque, Kyoto, Japan)], BrdU [mouse mAb, 1:200 (BD Biosciences, Franklin Lakes, NJ), and rat $\mathrm{mAb}$ (Oxford Biotechnology, Oxford, UK)], HuC/D (mouse mAb, 1:1000; Invitrogen), MAP2 (mouse mAb clone AP20 detecting a and $\mathrm{b}$ subunits, 1:100; Roche), $\beta$-tubulin type III (TuJ1) (mouse mAb, 1:5000; Babco, Richmond, CA), NeuN (mouse mAb, 1:200; Millipore, Temecula, CA), glial fibrillary acidic protein (GFAP) [mouse mAb, 1:1000 (Millipore) and rabbit pAb, 1:1000 (Sigma)], NG2 (mouse mAb, 
1:1000, and rabbit pAb, 1:1000; Millipore), myelin basic protein (MBP) (mouse mAb, 1:1000; Millipore), proteolipid protein (PLP) (mouse $\mathrm{mAb}, 1: 100$; Millipore), O4 (mouse IgM mAb, 1:400; Millipore), galactocerebroside (GalC) (mouse $\mathrm{mAb}, 1: 200$; Millipore), glutathione-Stransferase $\pi$ (GST- $\pi$ ) (mouse mAb, 1:50; Becton Dickinson), OX42 (mouse mAb clone CD11b, 1:50; Serotec, Raleigh, NC), RECA-1 (mouse $\mathrm{mAb}, 1: 5$; Serotec), choline acetyltransferase (ChAT) (rabbit pAb, 1:500; Millipore), $\gamma$-aminobutyric acid (GABA) (rabbit pAb, 1:500; Sigma), synaptophysin (mouse mAb, 1:100; Roche), and Mash1 (mouse mAb, 1:200; BD Biosciences).

For immunohistochemistry of tissue sections, rats were killed and fixed by intracardial perfusion of $4 \%(\mathrm{w} / \mathrm{v})$ paraformaldehyde (Acros, Geel, Belgium) in phosphate-buffered saline. Isolated spinal cord tissues were cryoprotected with $10-30 \%(\mathrm{w} / \mathrm{v})$ sucrose (Fisher Scientific, Pittsburgh, PA), and embedded into OCT compound (Sakura Finetek USA, Torrance, CA). Staining was visualized with appropriate sets of secondary antibodies conjugated with Alexa Fluor 350, 488, 568, 594, and 633 (1:200; Invitrogen) as described previously (Yamamoto et al., 2001b; Nakatomi et al., 2002).

To examine the total number of virus-infected cells in injured spinal cords, $14-\mu \mathrm{m}$-thick serial transverse sections were prepared from $5-\mathrm{mm}$ long spinal cord stumps $(2.5 \mathrm{~mm}$ each for rostral and caudal to the lesion epicenter). Among these serial sections, representative 12 sections, at least $280 \mu \mathrm{m}$ apart from each other, were subjected to immunostaining with GFP antibody. The number of $\mathrm{GFP}^{+}$cells in the entire area of each section was counted manually under Zeiss (Oberkochen, Germany) fluorescence microscope AxiophotoII. The sum of these numbers was multiplied with the number of total sections obtained from each samples ( $\sim 360$ sections), and then divided by 12 to yield the total number of $\mathrm{GFP}^{+}$cells per spinal cord.

To examine the coexpression of various cell type-specific markers in $\mathrm{GFP}^{+}$cells, six representative sections from the above serial transverse sections were double or triple stained for GFP and relevant markers. The entire area of the all sections was examined manually under fluorescence microscope. To further validate the costaining of multiple makers in single cells, 1-2 representative sections from each animal was further examined by confocal Z-sectioning at an interval of $1.0 \mu \mathrm{m}$ under Zeiss microscope LSM-501 as described previously (Nakatomi et al., 2002). Only cells that appeared to retain the intact soma and nuclei within a given section, which was judged according to the staining pattern of GFP, were counted.

To compare the coexpression of various markers in $\mathrm{GFP}^{+}$and $\mathrm{BrdU}^{+}$ cells, $14-\mu \mathrm{m}$-thick serial parasagittal sections were prepared from $8-\mathrm{mm}$ long spinal cord stumps ( $4 \mathrm{~mm}$ each for rostral and caudal to the lesion epicenter). Among these sections, six representative sections, which were at least $280 \mu \mathrm{m}$ apart from each other, were subjected to immunostaining. Costaining of individual $\mathrm{GFP}^{+}$and $\mathrm{BrdU}^{+}$cells with other markers was examined as described above by scanning the entire area of individual sections. As for $\mathrm{BrdU}^{+}$cells, cells that retained oval or round nuclear staining for BrdU were included for counting.

Statistical analysis. The quantitative results were expressed as mean \pm $\mathrm{SD}$, and the numbers of replicated experiments are shown in text or figure legends. Statistical analyses were performed with two-tailed unpaired $t$ test or one-way ANOVA.

\section{Results \\ Retrovirus-mediated genetic labeling of proliferative cells in the injured spinal cord}

Previous studies have demonstrated that endogenous NPCs proliferate in response to spinal cord injury (Johansson et al., 1999; Yamamoto et al., 2001a,b; Kojima and Tator, 2002; Horky et al., 2006). As a tool to genetically manipulate these proliferating progenitors in situ, we used replication-incompetent, recombinant retroviruses. Retroviruses almost exclusively infect dividing cells (Leber and Sanes, 1991; Horky et al., 2006). Thus, when directly administered to injured spinal cords, they are expected to infect proliferating NPCs together with other cell types. The retrovirus vector PMXIG used in this study was designed to express GFP so that virus-infected cells were detected as GFP-positive $\left(\mathrm{GFP}^{+}\right)$ cells (Morita et al., 2000; Yamamoto et al., 2001a,b).

Immediately after transection at the thoracic level, a small volume of high-titer pMXIG viruses was directly injected into the damaged parenchyma. At DAI3, virus-infected, $\mathrm{GFP}^{+}$cells were detected locally around the injected site. By DAI7, however, many $\mathrm{GFP}^{+}$cells spread out to broader areas, reaching at a distance of $\sim 2.5 \mathrm{~mm}$ from the lesion epicenter both rostrally and caudally (Fig. 1A). Some GFP-labeled cells were detected up to $4 \mathrm{~mm}$ away from the lesion. In the areas proximal $(<1 \mathrm{~mm})$ to the lesion, $\mathrm{GFP}^{+}$cells distributed in both the gray and white matters, which were revealed by costaining of GFP with the myelin protein MBP (Fig. $1 \mathrm{~B})$. At locations distal $(>2 \mathrm{~mm})$ to the lesion, however, more $\mathrm{GFP}^{+}$cells were detected in the $\mathrm{MBP}^{+}$white matter than in the gray matter where $\mathrm{NeuN}^{+}$neurons were densely populated (Fig. 1C). Given such widespread distribution of virus-infected cells, we included 8-mm-long spinal cord stumps encompassing the T8 to T12 columns for quantitative analyses. As a whole, $2.87 \pm 1.28 \times 10^{4}$ and $1.50 \pm 0.67 \times 10^{4} \mathrm{GFP}^{+}$cells were detected at DAI3 and DAI7, respectively, per spinal cord $(n=3)$ after infection with control viruses.

Both FGF2 and EGF are required for proliferation of adult spinal cord NPCs in vitro and in vivo (Weiss et al., 1996; Johansson et al., 1999; Yamamoto et al., 2001a,b; Kojima and Tator, 2002; Martens et al., 2002). Thus, to stimulate their proliferation in situ, we administered a mixture of FGF2 and EGF together with retroviruses ( $1 \mu \mathrm{g}$ each per animal). This GF treatment resulted in 1.6- and 2.7-fold increases in the number of $\mathrm{GFP}^{+}$cells at DAI3 and DAI7, respectively $\left(4.67 \pm 2.10 \times 10^{4}\right.$ cells at DAI3 and $4.00 \pm 1.80 \times 10^{4}$ cells at DAI7 per spinal cord, $n=3$ ). Moreover, the survival rate of $\mathrm{GFP}^{+}$cells between DAI3 and DAI7 was significantly higher in GF-treated animals $(85.6 \%)$ than that in untreated animals $(52.3 \%)(p<0.01$ in two-tailed unpaired $t$ test). These results suggest that GFs stimulated both proliferation and survival of virus-infected cells in vivo. Treatment with either FGF2 or EGF alone, or their combination at a lower dose $(0.1 \mu \mathrm{g}$ each) resulted in a much smaller increase $(<1.2$-fold $)$ in the number of $\mathrm{GFP}^{+}$cells at DAI7 (data not shown), suggesting a dose-dependent, combinatorial effect of FGF2 and EGF. We did not observe, however, any significant difference in the overall distribution pattern of $\mathrm{GFP}^{+}$cells within injured tissue between GF-treated and untreated animals. The extent of tissue damage and overall staining patterns of NeuN, MBP, GFAP, and OX42 also appeared to be similar between the two groups (data not shown). Thus, although GFs have been shown to exert pleiotropic effects in the injured spinal cord, including modulation of inflammatory responses, glial scar formation, and survival of neurons and glia (Cheng et al., 1996; Lee et al., 1999; Teng et al., 1999; Rabchevsky et al., 2000; Kojima and Tator, 2002; Meijs et al., 2004), we focused our analyses on their effects on the differentiation of GFP-labeled cells in this study.

\section{Properties of GFP virus-labeled cells in vivo}

We next examined the early phenotypes of $\mathrm{GFP}^{+}$cells in injured tissue. The infectability of retroviruses in vivo is lost in a relatively short period of time (Leber and Sanes, 1991; Horky et al., 2006). Therefore, when pMXIG viruses were administered immediately after transection, they are thought to preferentially label cells that proliferated early after injury. We compared such cells with those marked by the BrdU labeling method. Intraperitoneal administration of BrdU was initiated right after virus injection and subsequently repeated twice a day for $3 \mathrm{~d}$. In these animals, $28 \pm$ $6.2 \%$ of $\mathrm{GFP}^{+}$cells were colabeled with BrdU at DAI3, indicating 

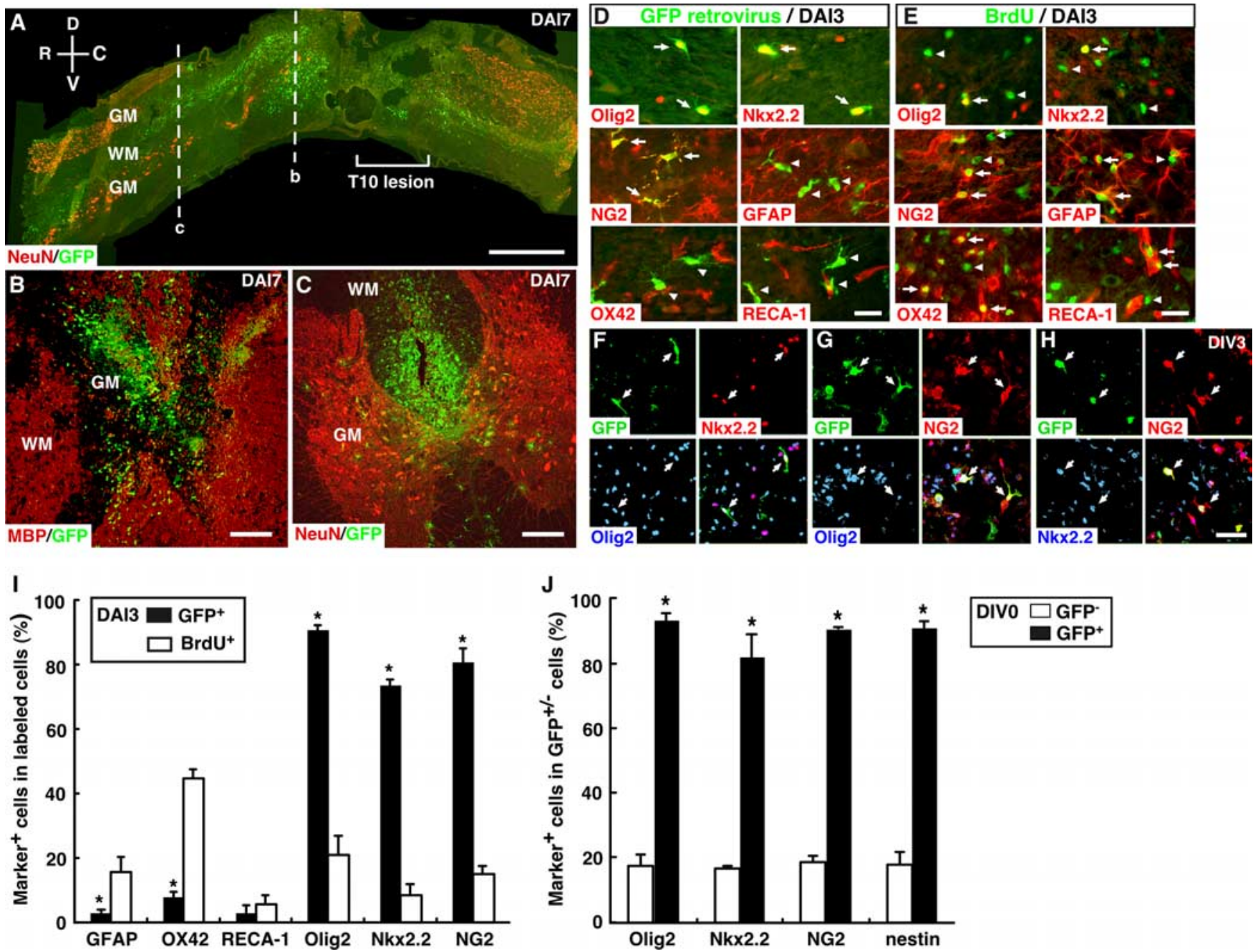

Figure 1. Distribution patterns and phenotypes of GFP virus-infected cells in the injured spinal cord. $\boldsymbol{A}-\boldsymbol{C}$, Micrographs of parasagittal $(\boldsymbol{A})$ and transverse $(\boldsymbol{B}, \boldsymbol{C})$ sections of spinal cords infected with GFP-expressing pMXIG recombinant retrovirus at DAI7. Distribution of virus-infected GFP cells (green) in the gray matter (GM) and white matter (WM) (red) was revealed by coimmunostaining of GFP with NeuN $(\boldsymbol{A}, \boldsymbol{C})$ and $\mathrm{MBP}(\boldsymbol{B})$, respectively. Dorsal $(D)$ is up, ventral $(V)$ is down, rostral $(R)$ is left, and caudal $(C)$ is right. Bracket in $A$ shows the location of the lesion epicenter at the T10 level. Right and left dashed lines in $\boldsymbol{A}$ indicate the approximate locations of the transverse sections shown in $\boldsymbol{B}$ and $\boldsymbol{C}$, respectively. $\boldsymbol{D}, \boldsymbol{E}$, Micrographs of double immunostaining of GFP ${ }^{+}(\boldsymbol{D})$ and BrdU ${ }^{+}$ (E) cells (green) with various cell type-specific markers (red) at DAI3. Arrows and arrowheads indicate GFP ${ }^{+}$cells positive and negative, respectively, for markers shown in each panel. $\boldsymbol{F}-\boldsymbol{H}$, Coexpression of Olig2, Nkx2.2, and NG2, and in GFP ${ }^{+}$cells. Dissociated single cells isolated from spinal cords treated with GFs and GFP viruses were subjected to triple immunostaining at DAl3. Arrows indicate cells positive for respective markers (shown in green, red, and blue in each panel), and the bottom-right panels are merged images. $I$, Histograms comparing the percentages of marker-positive cells in total GFP-labeled (filled bars) and BrdU-labeled (open bars) cells at DAI3. Data are mean \pm SD based on three independent experiments shown in $\boldsymbol{D}$ and $\boldsymbol{E}\left({ }^{*} p<0.001\right.$ compared with BrdU-labeled cells). J, Histograms comparing the expression of Olig2, Nkx2.2, NG2, and nestin between GFP ${ }^{+}$(filled bars) and GFP ${ }^{-}$(open bars) cell populations at DIV0. The percentages of GFP ${ }^{+}$and GFP ${ }^{-}$cells expressing respective markers were quantified (mean $\pm \mathrm{SD} ; n=3-5$ animals; ${ }^{*} p<0.01$ compared with GFP ${ }^{-}$cells). Scale bars: $\boldsymbol{A}, 1.0 \mathrm{~mm} ; \boldsymbol{B}, \boldsymbol{C}, 200 \mu \mathrm{m}$; $\boldsymbol{D}, \boldsymbol{E}, 50 \mu \mathrm{m}$; (in $\boldsymbol{H}) \boldsymbol{F}-\boldsymbol{H}, 20 \mu \mathrm{m}$.

that GFP viruses indeed infected a population of proliferative cells in vivo. However, $\mathrm{GFP}^{+} / \mathrm{BrdU}^{+}$cells comprised only $6 \%$ of total $\mathrm{BrdU}^{+}$cells, suggesting that the majority of BrdU-labeled cells proliferated after the period of virus infection. Consistent with our previous study (Yamamoto et al., 2001a), the major fractions of these $\mathrm{BrdU}^{+}$cells were $\mathrm{OX} 42^{+}$microglia and other inflammatory cells $(44.7 \%)$, RECA- $^{+}$vascular endothelial cells (5.6\%), and $\mathrm{GFAP}^{+}$astrocytes $(15.7 \%$ ) (Fig. $1 \mathrm{E}$, arrows, $I$ ); these cells, as a whole, comprised $66.0 \%$ of total $\mathrm{BrdU}^{+}$cells. In contrast, these cell types were rather minor among $\mathrm{GFP}^{+}$cells (14.2\% in total) (Fig. 1D,I), suggesting that cells other than these cell types were preferentially infected with viruses.

It has been shown that cells expressing the proteoglycan NG2 are one of the predominant proliferative cell types in both the intact and injured spinal cord (Horner et al., 2000; Ishii et al., 2001; McTigue et al., 2001; Dawson et al., 2003; Horky et al.,
2006). Previous studies have also demonstrated that cells expressing the transcription factors Olig2 and Nkx2.2 comprise subpopulations of proliferative cells in injured tissue (Yamamoto et al., 2001b; Han et al., 2004; Watanabe et al., 2004; Talbott et al., 2005). We found that the vast majority of $\mathrm{GFP}^{+}$cells detected at DAI3 expressed Olig2 (90.7 $\pm 1.5 \%)$, Nkx2.2 (73.7 $\pm 2.1 \%)$, and NG2 (80.7 $\pm 4.2 \% ; n=3$ animals) (Fig. $1 D, I)$. These cells did not overlap with $\mathrm{OX} 42^{+}, \mathrm{RECA}^{-}{ }^{+}$, or GFAP ${ }^{+}$cells (data not shown) (Yamamoto et al., 2001b; Watanabe et al., 2002, 2004; Talbott et al., 2005). However, the percentages of cells positive for these three markers among $\mathrm{BrdU}^{+}$cells were significantly lower than those among $\mathrm{GFP}^{+}$cells. Given the difference in the period of cell labeling, these suggest that cells expressing NG2, Olig2, and Nkx2.2 are predominant proliferative cell types early after injury. In line with this idea, when BrdU was administered only once at DAI0, the fractions of Olig ${ }^{+}$and $\mathrm{NG}^{+}$cells among total 
$\mathrm{BrdU}^{+}$cells significantly increased (59.6 \pm 3.2 and $53.3 \pm 4.7 \%$, respectively; $n=3$ animals), whereas the percentage of OX $42^{+} / \mathrm{BrdU}^{+}$cells became much lower $(23.4 \pm 1.1 \%)$ compared with those after repetitive injections for $3 \mathrm{~d}$. Conversely, when GFP viruses were administered at both DAI0 and DAI2, the percentage of Olig $2^{+} / \mathrm{GFP}^{+}$cells was significantly lower than that detected after single administration ( 37.1 vs $90.7 \% ; n=2$ animals). These results are in agreement with the recent report by Horky et al. (2006) in that $\mathrm{NG} 2^{+}$ cells proliferate early after injury, which is followed by expansion of $\mathrm{OX} 42^{+}$and $\mathrm{GFAP}^{+}$cells at later stages. Given these results, we chose the condition of single virus injection in subsequent studies.

The above results suggested that the majority of $\mathrm{GFP}^{+}$cells coexpressed all three markers. We further addressed this issue using dissociated single cell preparations (Fig. $1 F-H, J$ ). To avoid possible regional variability, cells were recovered from $8 \mathrm{~mm}$ spinal cord stumps where the entire population of $\mathrm{GFP}^{+}$cells distributed. In such preparations, $\mathrm{GFP}^{+}$cells comprised only $1.3 \pm 0.6 \%$ ( $n=6$ animals $)$ of total cells at DAI3. Among these $\mathrm{GFP}^{+}$cells, $93.3 \pm 2.1$ and $82.0 \pm 7.0 \%$ were Olig ${ }^{+}$and $\mathrm{Nkx} 2.2^{+}$, respectively (Fig. $\left.1 F-H, J\right)$. Likewise, $\mathrm{NG}^{+}$cells were highly enriched in the $\mathrm{GFP}^{+}$population $(90.7 \pm 0.6 \%)$. Furthermore, a series of triple staining demonstrated that the majority $(>80 \%)$ of $\mathrm{GFP}^{+}$cells were positive for all three markers (Fig. $1 \mathrm{~F}-H$ ). Most of these cells also expressed nestin and Sox2, commonly used markers for undifferentiated NPCs (Fig. 1J) (data not shown). These properties of $\mathrm{GFP}^{+}$cells were essentially identical between GF-treated and untreated animals at DAI3. Such cells, however, were $<20 \%$ among GFP ${ }^{-}$cells that represented the total cell population in injured tissue (Fig. $1 J)$.

We next sought to examine the frequency of $\mathrm{NG}^{+} / \mathrm{Olig} 2{ }^{+} /$ $\mathrm{Nkx} 2.2^{+}$cells, which comprised the major fraction of virusinfected cells (Fig. 2). Because triple staining of these three markers could not be performed because of technical reasons, we conducted a series of double staining. $\mathrm{NG}^{+}$cells comprised $6.5 \pm 1.1 \%$ of total cells in the intact spinal cord, and among these $\mathrm{NG} 2{ }^{+}$cells, $\mathrm{NG}_{2}{ }^{+} / \mathrm{Olig} 2{ }^{+}$and $\mathrm{NG} 2{ }^{+} / \mathrm{Nkx} 2.2^{+}$cells were 43 and $60 \%$, respectively (Fig. $2 A$ ). Likewise, only a fraction of Olig ${ }^{+}$cells expressed NG2 and Nkx2.2 [20\% $(2.8 \div 14.2)$ and $35 \%(5.0 \div 14.2)$, respectively], and only $74 \%(5.0 \div 6.8)$ and $57 \%(3.9 \div 6.8)$ of $\mathrm{Nkx} 2.2^{+}$cells coexpressed Olig2 and NG2, respectively. Thus, in terms of the coexpression of these markers, heterogeneous cell types coexisted in the spinal cord, consistent with the results of previous studies (Yamamoto et al., 2001b; Watanabe et al., 2004; Talbott et al., 2005; Kitada and Rowitch, 2006). Using the Venn diagram based on these results, we estimated that $\mathrm{NG}^{+} / \mathrm{Olig} 2^{+} / \mathrm{Nkx} 2.2^{+}$cells comprised $2.1-2.8 \%$ of the total cells in the intact spinal cord (Fig. $2 B$ ), which corresponded to $30-40 \%$ of total $\mathrm{NG} 2^{+}$cells. The fact that the vast majority of $\mathrm{GFP}^{+}$virus-labeled cells coexpressed three markers indicates that such triple positive cells indeed exist in vivo. After transection injury, this cell population increased to $3.9-6.0 \%$ mainly because of a net increase (2.3-fold) in the number of $\mathrm{NG}_{2}{ }^{+}$cells as observed under other injury conditions such as contusion and demyelination (Watanabe et al., 2004; Talbott et al., 2005; Horky et al., 2006; Kitada and Rowitch, 2006).

\section{Neurosphere formation by GFP virus-labeled cells}

We next asked whether cells infected with GFP viruses in vivo contained NPCs. Here, we operationally define NPCs as the cells that can grow as neurospheres in the presence of GFs and differentiate into neurons and glia after removal of GFs in vitro (Weiss et al., 1996; Johansson et al., 1999; Yamamoto et al., 2001b; Martens et al., 2002). Injured spinal cords treated with GFP viruses and GFs were dissociated into single cells at DAI3, and NPCs were subsequently expanded as floating neurospheres. Although the frequency of $\mathrm{GFP}^{+}$cells among initial viable cells was very low $(1.3 \pm 0.6 \%$ at DIV0; $n=6)$, they were significantly enriched (6.3-fold) in neurosphere culture; $8.2 \pm 1.2 \%$ of total cells recovered as neurospheres were $\mathrm{GFP}^{+}$at DAI14 $(n=4 ; p<0.01$ compared with DAI0 in two-tailed unpaired $t$ test) (Fig. $3 A-C$ ). About one-third of $\mathrm{GFP}^{+}$neurospheres were entirely composed of $\mathrm{GFP}^{+}$cells (Fig. $3 B, B^{\prime}$ ), and they repeatedly formed $\mathrm{GFP}^{+}$ spheres after passages (data not shown). Given the low frequency of $\mathrm{GFP}^{+}$cells in the original samples subjected to culture, such purely $\mathrm{GFP}^{+}$neurospheres were likely to have derived from single $\mathrm{GFP}^{+}$cells. The majority of these $\mathrm{GFP}^{+}$cells in primary neurospheres expressed Olig2 and Nkx2.2 (90.5 \pm 6.4\% for Olig2 and $81.7 \pm 4.2 \%$ for $\mathrm{Nkx} 2.2 ; n=3$ ) (Fig. $3 D, E, H$ ). About onethird of $\mathrm{GFP}^{+}$cells were also NG2 ${ }^{+}(32.0 \pm 6.6 \% ; n=3)$ (Fig. $3 F, H$ ) and nestin ${ }^{+}$(Fig. 3G). Importantly, cells positive for these markers were also the predominant cell type in virus uninfected, GFP ${ }^{-}$neurospheres (Fig. $3 H$ ), despite that such cells were rather minor among $\mathrm{GFP}^{-}$cells before neurosphere formation (Fig. $1 \mathrm{~J})$.

After removal of GFs, both $\mathrm{GFP}^{+}$and $\mathrm{GFP}^{-}$neurospheres gave rise to $\mathrm{TuJ}_{1}{ }^{+}$neurons, $\mathrm{GFAP}^{+}$astrocytes, and $\mathrm{O}^{+}{ }^{+}$oligodendrocytes (Fig. 3I,I'). By a series of triple staining, we confirmed that most $(>95 \%)$ of the $\mathrm{GFP}^{+}$spheres composed entirely of $\mathrm{GFP}^{+}$cells contained all three neural lineages (data not shown). Because the ratio of neurons and glia was variable among individual neurospheres, the percentages of cells expressing neuronal and glial markers were quantified using preparations of 

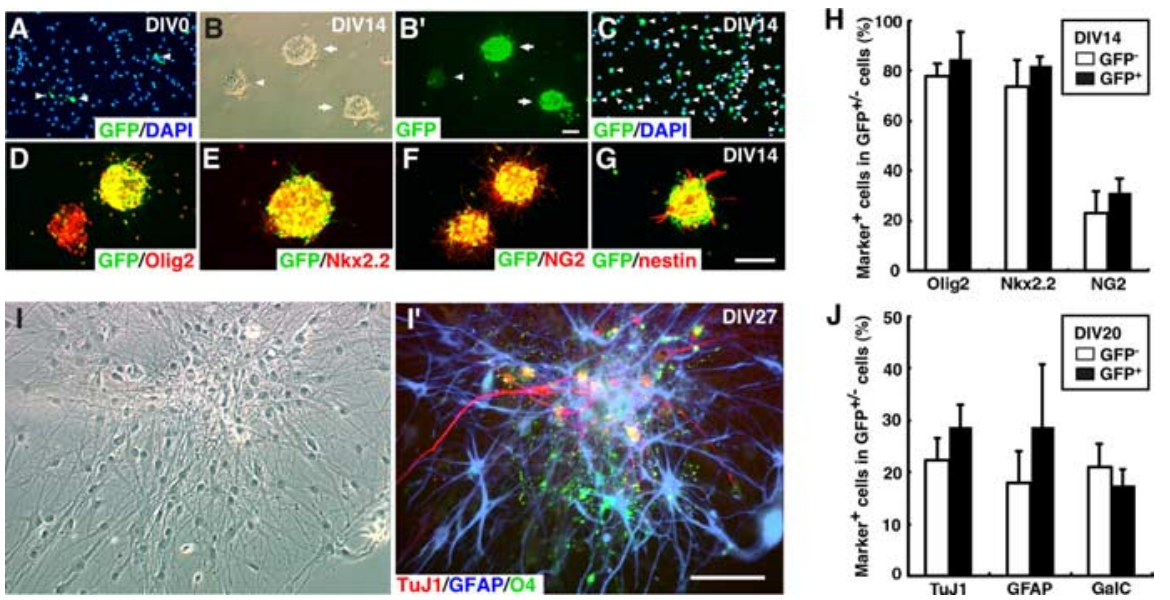

Figure 3. Neurosphere formation by GFP virus-labeled cells in vitro. $\boldsymbol{A}-\boldsymbol{C}$, In vitro expansion of GFP ${ }^{+}$cells as neurospheres. $\boldsymbol{A}$ and $C$ show immunostaining of GFP (green) and nuclear staining with DAPI (blue) in dissociated single cells at DIV0 and DIV14, respectively, in neurosphere culture. The frequency of GFP ${ }^{+}$cells in the initial cell population at DIV0 was very low $(\boldsymbol{A}$, arrowheads), but they were highly enriched in neurospheres at DIV14 ( $\boldsymbol{C}$, arrowheads). $\boldsymbol{B}$ and $\boldsymbol{B}^{\prime}$ are bright-field and fluorescence images of GFP ${ }^{+}$(arrows) and GFP ${ }^{-}$(arrowhead) neurospheres, respectively, at DIV14. D-G, The expression of Olig2, Nkx2.2, NG2, and nestin (red) in GFP ${ }^{+}$neurospheres (green) at DIV14. $\boldsymbol{H}$, Histograms comparing the percentages of Olig2 ${ }^{+}, \mathrm{Nkx}_{2} .2^{+}$, and NG2 ${ }^{+}$ cells in total GFP ${ }^{+}$(filled bars) and GFP ${ }^{-}$(open bars) neurosphere cells at DIV14 (mean \pm SD; $n=3-5$ independent cultures). $\boldsymbol{I}, \boldsymbol{I} \boldsymbol{I}$, Differentiation of neurosphere cells. Bright-field $(\boldsymbol{I})$ and fluorescence $(\boldsymbol{I})$ images of a secondary neurosphere stained for TuJ1 (red), GFAP (blue), and 04 (green). Cells were induced to differentiate for $6 \mathrm{~d}$ between DIV21 and DIV26 on a PDL-coated glass chamber. J, Differentiation of GFP ${ }^{+}$and GFP ${ }^{-}$neurosphere cells into neurons and glia. Primary neurospheres at DIV14 were dissociated into single cells and induced to differentiate in monolayer for $6 \mathrm{~d}$. The percentages of GFP ${ }^{+}$and GFP ${ }^{-}$cells expressing respective neuronal and glial cell markers were quantified (mean $\pm \mathrm{SD} ; n=3-6$ independent cultures). Scale bars: (in $\boldsymbol{G}) \boldsymbol{A}, \boldsymbol{C}$, D-G, $100 \mu \mathrm{m}$; (in $\boldsymbol{B}^{\prime}$ ) $\boldsymbol{B}, \boldsymbol{B}^{\prime}, 50 \mu \mathrm{m}$; (in $\left.\boldsymbol{I}^{\prime}\right) \boldsymbol{I}, \boldsymbol{I}^{\prime}, 20 \mu \mathrm{m}$.
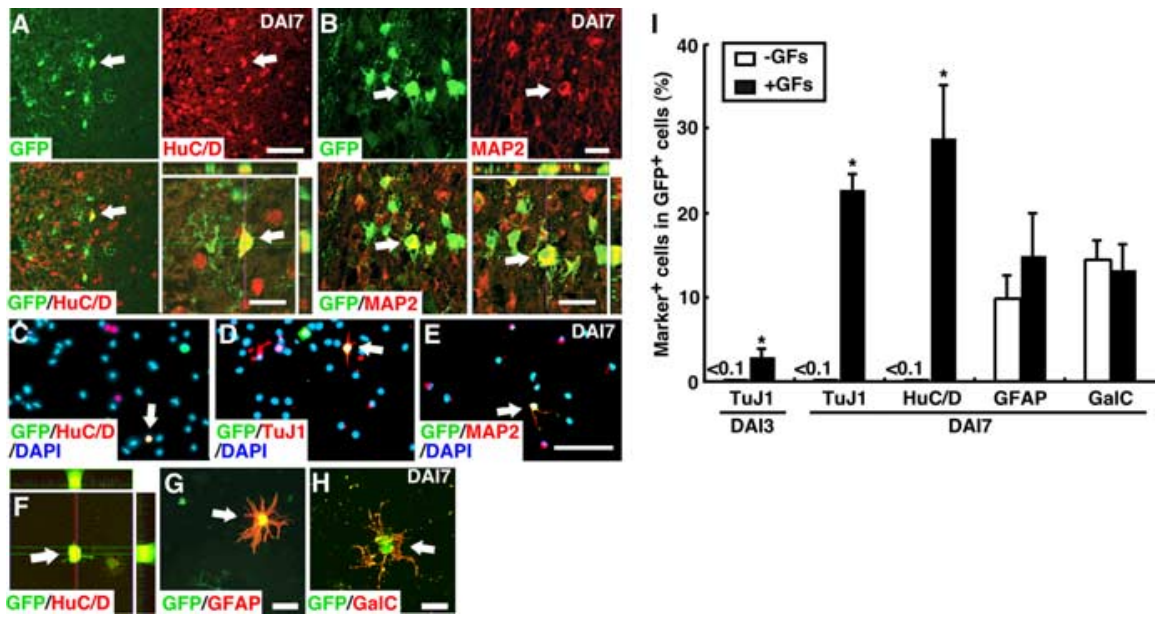

Figure 4. Induction of new neurons by GFs in injured spinal cords. $A, B$, Micrographs showing the expression of the neuronal markers HuC/D ( $\boldsymbol{A})$ and MAP2 (B) (red) in GFP ${ }^{+}$cells (arrows) at DAI7. The bottom-right panel in each set shows a threedimensional digital image of the cell indicated by arrows in the other panels. $\boldsymbol{C}-\boldsymbol{H}$, Expression of various neuronal and glial cell markers in GFP ${ }^{+}$cells at DAI7. Dissociated single cells prepared from GF-treated spinal cords were subjected to double staining of GFP (green) with HuC/D $(\boldsymbol{C}, \boldsymbol{F})$, TuJ1 (D), MAP2 $(\boldsymbol{E}), \operatorname{GFAP}(\boldsymbol{G})$, and GaIC $(\boldsymbol{H})$. Arrows indicate double stained cells. In $\boldsymbol{C}-\boldsymbol{E}$, cell nuclei were stained with DAPI (blue). $\boldsymbol{F}$, A set of three-dimensional confocal images of a $\mathrm{GFP}^{+} / \mathrm{HuC} / \mathrm{D}^{+}$cell. $\boldsymbol{I}$, Induction of neuronal differentiation of GFP ${ }^{+}$cells in vivo by GFs. Dissociated cells were prepared from spinal cords treated with (filled bars) and without (open bars) GFs at DAI3 (left) and DAI7 (right), and the percentages of GFP ${ }^{+}$cells expressing respective neuronal and glial markers were quantified (mean $\pm S D ; n=3-6$ animals) ${ }^{*} p<0.01$ compared with untreated animals. Scale bars: (in $\left.\boldsymbol{E}\right) \boldsymbol{A}, \boldsymbol{C}-\boldsymbol{E}, 50 \mu \mathrm{m}$; $\boldsymbol{B}$ and three-dimensional images in $\boldsymbol{A}, 20 \mu \mathrm{m}$; (in $\boldsymbol{G}, \boldsymbol{H}$ ) $\boldsymbol{F}, \boldsymbol{G}, \boldsymbol{H}, 10 \mu \mathrm{m}$.

dissociated single cells. We found that $\mathrm{GFP}^{+}$cells contained all three neural cell lineages, and that the percentages of neurons and glia were essentially identical between $\mathrm{GFP}^{+}$and $\mathrm{GFP}^{-}$cell populations (Fig. 3J). Altogether, these results demonstrate that a fraction of GFP-labeled, virus-infected cells indeed exhibited the properties of NPCs.

\section{Induction of new neurons by} growth factors

We next examined differentiation of retrovirus-infected cells in vivo. Without administration of GFs, no $\mathrm{GFP}^{+}$cells expressing neuronal markers were detectable at any time point examined (Fig. $4 \mathrm{I}$ ) (data not shown), indicating that viruses did not infect pre-existing postmitotic neurons. In contrast, we found that in GF-treated spinal cords, a significant fraction of $\mathrm{GFP}^{+}$ cells expressed the immature neuronal markers $\mathrm{HuC} / \mathrm{D}, \mathrm{TuJ} 1$, and $\mathrm{c}$ subunit of MAP2 at DAI3 and DAI7 (Fig. 4A,B,I). The costaining of GFP and these markers in the same cells was confirmed under confocal microscope (Fig. $4 A, B$, bottom right). Such cells were detected in both the gray and white matters, and their distribution pattern varied among sections examined. The size (9-14 $\mu \mathrm{m}$ in diameter) and shape (round, oval, or spindle) of their soma were also variable at different locations. Yet, they commonly harbored multiple thin processes, typical of differentiating immature neurons. None of these $\mathrm{GFP}^{+}$/neuronal marker-positive cells, however, coexpressed NeuN, a marker commonly used to identify mature neurons (see below). Given the fact that the vast majority of neurons in the adult spinal cord are $\mathrm{NeuN}^{+}$, these results reinforce the idea that GFP viruses did not infect pre-existing neurons.

To further validate the coexpression of neuronal markers and GFP in single cells, GF-treated tissue was dissociated into single cells and seeded on poly-D-lysinecoated dishes. $\mathrm{GFP}^{+} /$neuronal markerpositive cells immediately attached to the culture surface and actively extended processes within $2 \mathrm{~h}$ after plating (Fig. $4 C-F$ ). Thus, they were indeed live neurons, not dead or dying cells. None of these cells harbored multiple or abnormally enlarged nuclei; hence, it is unlikely that fusion between non-neuronal cells and pre-existing neurons, which is known to occur at an extremely low but yet detectable rate in injured adult tissue (Alvarez-Dolado et al., 2003), accounted for the emergence of $\mathrm{GFP}^{+} /$neuronal marker-positive cells. Moreover, when BrdU was coadministered with GFs between DAI0 and DAI2, a small number of $\mathrm{BrdU}^{+} / \mathrm{TuJ} 1^{+}$cells (four cells among total $1090 \mathrm{BrdU}^{+}$cells examined; $0.37 \%$ ) were detected at DAI7, although such cells were never detected in GF-untreated animals (data not shown) (Yamamoto et al., 2001a,b). Thus, the results using both BrdU and GFP viruses supported the idea that new neurons were generated from endogenous cells in GF-treated spinal cords. It has been shown that the expression of various GFs including FGF2 is upregulated after injury (Mocchetti et al., 1996; 
Nakamura and Bregman, 2001; Velardo et al., 2004). Given the observed effect of exogenously administered GFs, however, it appears that their endogenous levels are not sufficient to support neurogenesis in the injured spinal cord. This is in sharp contrast to the situation in other parts of the CNS, where detectable neurogenesis occurs after injury without treatment with exogenous GFs (Arvidsson et al., 2002; Nakatomi et al., 2002; Teramoto et al., 2003).

We next quantitatively assessed the induction of new neurons by GFs. At DAI3, $3.0 \pm 0.7 \%$ of $\mathrm{GFP}^{+}$cells (19 positive cells/652 cells examined; $n=3$ animals) were $\mathrm{TuJ} 1^{+}$, and this percentage increased to $22.8 \pm 1.9 \%$ at DAI7 (224 cells/995 $\mathrm{GFP}^{+}$cells examined; $n=4$ animals) (Fig. $4 I)$. At DAI7, $28.9 \pm 6.2$ and $4.2 \pm 1.4 \%$ of $\mathrm{GFP}^{+}$cells were also $\mathrm{HuC} / \mathrm{D}^{+}$and $\mathrm{MAP}^{+}{ }^{+}$, respectively. The percentage of $\mathrm{GFP}^{+} / \mathrm{HuC} / \mathrm{D}^{+}$cells in animals treated with a lower dose of GFs was much smaller $(<5 \%)$, suggesting a dose-dependent effect of GFs on neuronal differentiation. Given that $4.67 \times 10^{4}$ and $4.00 \times 10^{4}$ $\mathrm{GFP}^{+}$cells were detected at DAI3 and DAI7, respectively, the estimated number of $\mathrm{GFP}^{+} / \mathrm{TuJ} 1^{+}$cells was $1.40 \times 10^{3}$ at DAI3 and $9.10 \times 10^{3}$ at DAI7 per GFtreated animal $(n=3)$. Thus, new neurons substantially increased in number between DAI3 and DAI7 $(p<0.01)$, whereas the total number of GFP ${ }^{+}$ cells rather decreased to $86 \%$ during this period. This timedependent increase in the actual number of $\mathrm{GFP}^{+} /$neuronal marker-positive cells reinforces the idea that such cells were unlikely to be products of cell fusion between pre-existing neurons and non-neuronal cells, or mere artifacts in histology. Furthermore, albeit that GF-treatment increased the number of GFP ${ }^{+}$ cells only 1.6-fold at DAI3 and 2.7-fold at DAI7, GFP ${ }^{+}$cells expressing neuronal markers were not detected at all in untreated animals. These results are consistent with the idea that GFs not only stimulated proliferation of endogenous NPCs, but also promoted their neuronal differentiation in vivo. GFs might have supported the survival of newly generated neurons as well, but such a survival effect could not fully account for the observed increase in the number of new neurons between DAI3 and DAI7. We found, however, that the numbers of $\mathrm{GFP}^{+} / \mathrm{TuJ} 1^{+}$and $\mathrm{GFP}^{+} / \mathrm{HuC} / \mathrm{D}^{+}$ cells gradually decreased after DAI7, and they eventually disappeared by DAI28 (data not shown). In addition, as described above, no $\mathrm{GFP}^{+}$cells were found to express NeuN, which features a more mature phenotype of neurons, at any time points examined when control viruses were used for infection (see below).

Unlike these neuronal cells, substantial fractions of $\mathrm{GFP}^{+}$ cells expressed glial cell markers GFAP (Fig. 4G) and GalC (Fig. $4 H$ ) without treatment with GFs, and their percentages were not significantly different between GF-treated and untreated animals ( $p=0.160$ for $\mathrm{GFAP}^{+}$cells and $p=0.327$ for $\mathrm{GalC}^{+}$cells) (Fig. $4 I)$. Few $\mathrm{GFP}^{+}$or BrdU ${ }^{+}$cells were $\mathrm{GalC}^{+}$at earlier time points, suggesting that $\mathrm{GFP}^{+} / \mathrm{GalC}^{+}$cells detected at DAI7 were newly generated oligodendrocytes. In fact, it has been demonstrated that immature oligodendrocytes are generated in both the intact and injured spinal cord (McTigue et al., 1998, 2001; Horner et al., 2000; Ishii et al., 2001; Watanabe et al., 2002, 2004; Talbott et al., 2005; Yang et al., 2006). Nevertheless, we detected no GFP ${ }^{+}$cells expressing MBP or PLP, markers for myelin-forming oligodendrocytes, at any time points examined in either GF-treated or untreated animals. Thus, the maturation of oligodendrocytes appeared to be limited in injured tissue (see below). Unlike these cells in the oligodendrocyte lineage, many $\mathrm{GFP}^{+} / \mathrm{GFAP}^{+}$and $\mathrm{BrdU}^{+} / \mathrm{GFAP}^{+}$astrocytes were detected at both DAI3 and DAI7 (Figs. 1I, 4I). Because mature astrocytes are known to retain the ability of cell divisions, it remained undetermined to what extent $\mathrm{GFP}^{+} / \mathrm{GFAP}^{+}$cells reflected de novo differentiation of NPCs into the astrocyte lineage.

\section{Enhanced neurogenesis by Neurogenin 2 and BDNF in vitro}

The above study demonstrated that the production of new neurons from endogenous NPCs can be induced under certain conditions. This, in turn, suggests the presence of certain mechanisms that actively suppress the neurogenic potential of NPCs in situ. We first addressed this issue using in vitro culture of NPCs. To mimic the situation of virus-infected NPCs in vivo, growing neurosphere cells were infected with pMXIG viruses, and subsequently, neuronal and glial differentiation of $\mathrm{GFP}^{+}$cells after removal of GFs was examined (Fig. 5).

It has been shown that the expression of various cytokines is significantly upregulated in the injured spinal cord (Nakamura and Bregman, 2001; Setoguchi et al., 2001, 2004; Velardo et al., 2004; Chen et al., 2005). Among them, BMPs and CNTF have been shown to inhibit neuronal differentiation of NPCs both in vivo and in vitro (Lim et al., 2000; Nakashima et al., 2001; Setoguchi et al., 2004). Consistent with this, treatment of neurospheres with BMP4 and CNTF significantly increased the percentage of 
A

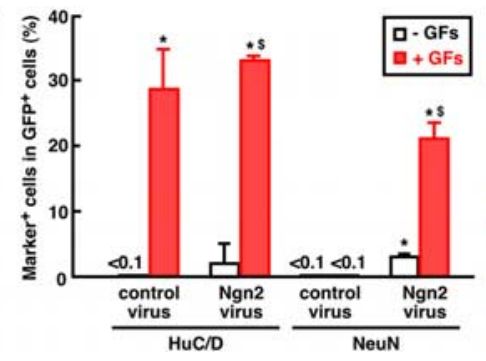

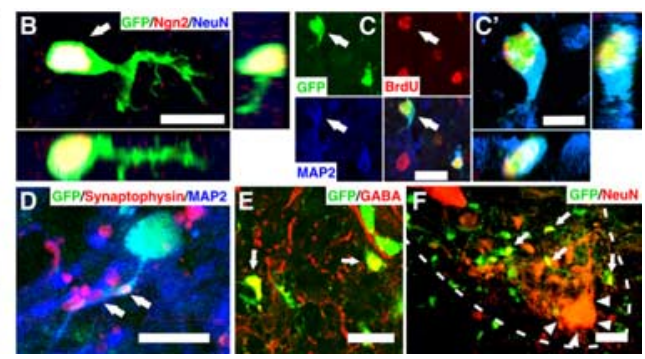

Figure 6. Induction of new neurons by GFs, Ngn2, and BDNF in vivo. $\boldsymbol{A}$, Effects of GFs and Ngn2 on neuronal differentiation of GFP-labeled cells in vivo. Control and Ngn2 viruses were administered with (red bars) or without (white bars) GFs into injured spinal cords, and subsequently the percentages of HuC/D ${ }^{+}$(left) and NeuN ${ }^{+}$(right) cells among total GFP ${ }^{+}$cells were quantified at DAI7. GFP ${ }^{+} / \mathrm{HuC} / \mathrm{D}^{+}$cells were detected in dissociated single cells, whereas $\mathrm{GFP}^{+} / \mathrm{NeuN}^{+}$cells were detected in tissue sections. ${ }^{*} p<0.01$ compared with control virus-infected animals. ${ }^{\$} p<0.01$ compared with Ngn2 without GFs. B-F, Micrographs showing GFP ${ }^{+}$cells (green) costained for Ngn2 (red) and NeuN (blue) (B) and BrdU (red) and MAP2 (blue) (C, $\boldsymbol{C}^{\prime}$ ) at DAI7, synaptophysin (red) and MAP2 (blue) (D), GABA (red) (E), and NeuN (red) (F) at DAI28. $\boldsymbol{C}^{\prime}$ shows a magnified view of a neurons indicated by arrow in $\boldsymbol{C}$. The right and bottom panels in $\boldsymbol{B}$ and $\boldsymbol{C}$ 'show three-dimensional digital images of cells triple positive for respective markers. Note that the overlap of green, red, and blue colors in single cells results in white color. Arrows in $D$ indicate synaptophysin ${ }^{+}$ dense speckles associated with processes of $\mathrm{GFP}^{+} / \mathrm{MAP2}^{+}$cells. Arrows in $\boldsymbol{E}$ and $\boldsymbol{F}$ indicate $\mathrm{GFP}^{+} / \mathrm{GABA}^{+}$and GFP ${ }^{+} / \mathrm{NeuN}^{+}$cells, respectively. A dashed line in $\boldsymbol{F}$ demarcates the position of the anterior horn where $\mathrm{GFP}^{+} / \mathrm{NeuN}^{+}$small interneuron-like cells intermingled with large motoneurons (indicated by arrowheads). Scale bars: $\boldsymbol{B}, \boldsymbol{C}^{\prime}, 10 \mu \mathrm{m} ; \boldsymbol{C}, \boldsymbol{D}, \boldsymbol{E}, 20 \mu \mathrm{m} ; \boldsymbol{F}, 50 \mu \mathrm{m}$. became $\mathrm{TuJ} 1^{+}$compared with $1.7 \pm 0.3 \%$ in the control culture $(p<0.0001 ; n=3)$ (Fig. $5 C$ ). Under the same conditions, the percentages of $\mathrm{GFAP}^{+}$astrocytes and $\mathrm{O}^{+}$oligodendrocytes were not significantly different between control and Ngn2 virus-infected cells (data not shown) (Yamamoto et al., 2001b). Importantly, the neurogenic action of Ngn2 was preserved in the presence of exogenous BMP4 and CNTF. Even a higher percentage of Ngn2-expressing NPCs differentiated into neurons in the presence of BMP4 than in its absence $(p<0.001)$, consistent with a previous study using embryonic brainderived NPCs (Sun et al., 2001). Moreover, BDNF, which promotes differentiation and survival of new neurons in the adult CNS (Namiki et al., 2000; Coumans et al., 2001; Chmielnicki et al., 2004), increased the percentage of $\mathrm{TuJ} 1^{+}$neurons generated by Ngn2-expressing cells $(29.4 \pm 1.0 \% ; n=3 ; p<0.005)$.
$\mathrm{GFAP}^{+}$astrocytes among total $\mathrm{GFP}^{+}$cells, and this occurred at the expense of $\mathrm{TuJ} 1^{+}$neurons and $\mathrm{O}_{4}{ }^{+}$oligodendrocytes $(p<$ 0.001 for both BMP4 and CNTF) (Fig. 5A). These factors did not significantly alter the rate of cell proliferation or death of either $\mathrm{GFP}^{+}$or $\mathrm{GFP}^{-}$cells in culture (data not shown) and, thus, the observed effects most likely reflected their actions on differentiation of NPCs. Conversely, the extracellular BMP inhibitor noggin decreased the fraction of $\mathrm{GFAP}^{+}$cells (Fig. 5A). Retrovirusmediated overexpression of Smad6 and Smad7, which block intracellular signaling for BMP4, also exerted the same effect (Fig. $5 B)$. Likewise, a dominant-negative $(\mathrm{dn})$ form of STAT3 (Kamakura et al., 2004), which inhibits the activity of endogenous STAT3, the major intracellular signal transducer downstream of CNTF receptors (Sun et al., 2001; Kamakura et al., 2004), increased the percentages of $\mathrm{TuJ}_{1}{ }^{+}$and $\mathrm{O} 4{ }^{+}$cells $(p<0.001$ for TuJ1 and $p<0.01$ for O4) (Fig. 5B). These results suggest that BMP4 and CNTF (or related cytokines) are expressed by NPCs themselves and/or their progeny, and that such endogenous factors inhibit neurogenesis in an autocrine and/or paracrine manner. This could be one of the mechanisms by which neuronal differentiation of NPCs is attenuated in vivo. However, the effect of blocking the actions of these endogenous cytokines on neurogenesis was rather weak: $<5 \%$ of total $\mathrm{GFP}^{+}$cells differentiated into neurons under the conditions in which cytokine signals were attenuated by Smad6/7, dn-STAT3, or both (Fig. 5B) (data not shown). Furthermore, the stimulatory effect of noggin on neuronal differentiation of NPCs appears to be variable in vivo (Setoguchi et al., 2004; Enzmann et al., 2005).

We therefore tested another strategy to enhance neurogenesis by NPCs. Our previous study suggested that signaling through the cell-surface receptor Notch is involved in the inhibition of neuronal differentiation of NPCs, and that overexpression of the neurogenic transcription factor Ngn2 can overcome such inhibition (Yamamoto et al., 2001b). A more recent study has also shown that Ngn2 enhances neuronal differentiation of grafted, exogenous NPCs in vivo (Hofstetter et al., 2005). Then, we tested whether Ngn2 can also stimulate neurogenesis in the presence of BMP4 and CNTF in vitro. When neurospheres were infected with Ngn2-expressing retroviruses, $23.9 \pm 1.7 \%$ of total $\mathrm{GFP}^{+}$cells

\section{Stimulation of neurogenesis by Ngn2 and BDNF in vivo}

Based on these in vitro results, we next tested the activities of Ngn2 viruses and BDNF in vivo. Unlike control virus-infected cells, a small, but significant percentage of Ngn2 virus-infected cells became $\mathrm{HuC} / \mathrm{D}^{+}(2.3 \pm 3.2 \% ; n=3)$ and $\mathrm{NeuN}^{+}(3.0 \pm$ $0.1 ; n=3)$ at DAI7 even without cotreatment with GFs (Fig. 6A). Furthermore, when combined with GFs, much larger fractions of Ngn2-expressing cells become $\mathrm{HuC} / \mathrm{D}^{+}$and NeuN ${ }^{+}(33.3 \pm 0.6$ and $21.1 \pm 2.3 \%$, respectively; $n=3$ animals; $p<0.01$ ). In the presence of GFs, however, the percentages of $\mathrm{GFP}^{+} / \mathrm{HuC} / \mathrm{D}^{+}$ cells did not significantly differ between control and Ngn2 virusinfected animals ( $p=0.1404$ ). Thus, GF treatment appeared to exert a stronger effect than Ngn2 overexpression on the generation of $\mathrm{HuC} / \mathrm{D}^{+}$immature neurons in vivo. Yet, the combination of Ngn2 and GFs showed a much stronger activity to induce $\mathrm{GFP}^{+} / \mathrm{NeuN}^{+}$cells compared with those of GFs and Ngn2 alone $(p<0.01)$, suggesting that these two manipulations collaborate to induce $\mathrm{NeuN}^{+}$neurons.

The coexpression of Ngn2 confirmed that $\mathrm{GFP}^{+} / \mathrm{NeuN}^{+}$ neurons were derived from Ngn2 virus-infected cells (Fig. $6 B$ ). Moreover, many $\mathrm{GFP}^{+} / \mathrm{NeuN}^{+}$cells were also labeled with BrdU administered between DAI0 and DAI2, indicating that such cells were indeed generated by cells that proliferated in situ (Fig. 6C). Under our experimental conditions, control and Ngn2 viruses are thought to infect the same cells population in situ with or without GFs. Nevertheless, $\mathrm{GFP}^{+} / \mathrm{NeuN}^{+}$cells were detected only in Ngn2 virus-infected animals. Thus, we conclude that the possibility that the costaining of GFP and NeuN was caused by certain artifacts is highly unlikely.

As shown in Figure 6, $C$ and $D$, many $\mathrm{GFP}^{+}$cells in Ngn2 virus-infected tissues developed thick processes with intense MAP2 staining. Their soma and processes were often associated with synaptophysin ${ }^{+}$dense speckles reminiscent of synaptic buttons of surrounding preexisting neurons (Fig. $6 D$, arrows), suggesting more mature properties of $\mathrm{GFP}^{+} / \mathrm{NeuN}^{+}$neurons than those of $\mathrm{GFP}^{+} / \mathrm{HuC} / \mathrm{D}^{+}$cells. Most $(>95 \%)$ of these $\mathrm{GFP}^{+} /$ $\mathrm{NeuN}^{+}$neurons were positive for GABA (Fig. $6 \mathrm{E}$ ), but negative for choline acetyltransferase or glycine (data not shown), suggesting that they differentiated into certain types of interneurons. For 

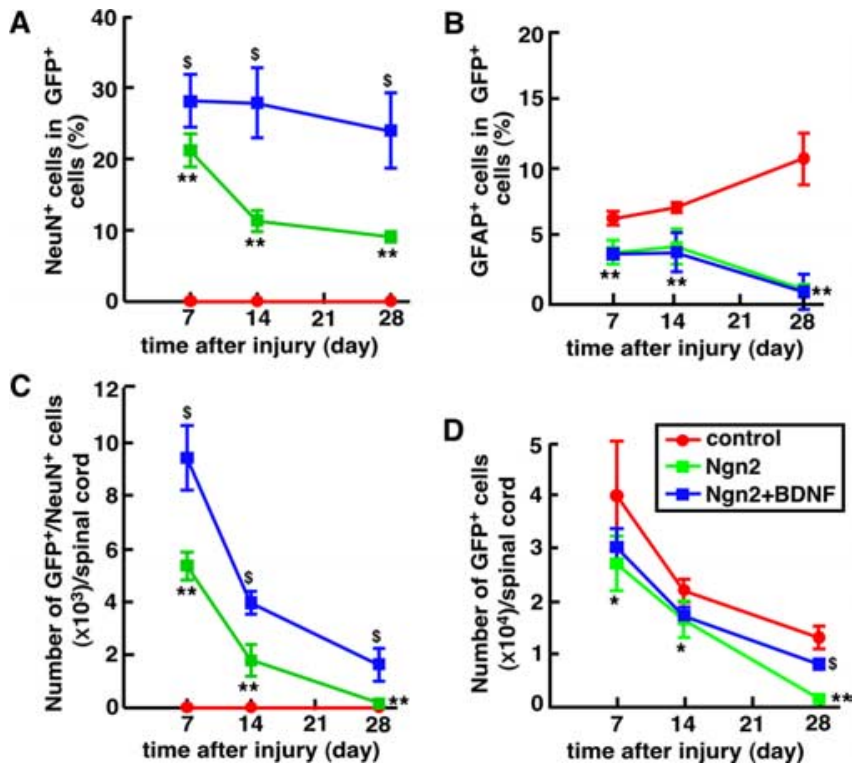

Figure 7. Survival of newly generated neurons in injured spinal cords. $\boldsymbol{A}-\boldsymbol{D}$, Percentages of $\mathrm{NeuN}^{+}(\boldsymbol{A})$ and GFAP ${ }^{+}(\boldsymbol{B})$ cells among total GFP ${ }^{+}$cells, and estimated numbers of GFP ${ }^{+}$/ $\mathrm{NeuN}^{+}(\boldsymbol{C})$ and total GFP ${ }^{+}(\boldsymbol{D})$ cells were quantified at various time points after injury. Injured spinal cords were treated with GFs and control viruses (red lines), GFs and Ngn2 viruses (green), and GFs, BDNF, and Ngn2 viruses (blue). All data are mean \pm SD (3-12 independent experiments; ${ }^{*} p<0.05$ and ${ }^{* *} p<0.01$ compared with control virus infection; ${ }^{\$} p<0.01$ compared with Ngn2 virus infection alone).

example, $\mathrm{GFP}^{+} / \mathrm{NeuN}^{+}$cells detected in the anterior horn were scattered within a cluster of large motor neurons and smaller interneurons, but their soma size $(10-19 \mu \mathrm{m}$ in diameter; $14.4 \pm$ $3.3 \mu \mathrm{m} ; n=6$ ) was similar to that of the latter subtype (14.5 \pm 3.7 $\mu \mathrm{m} ; n=8$ ) (Fig. $6 F$ ). However, the morphology and location of individual $\mathrm{GFP}^{+} / \mathrm{NeuN}^{+}$cells were highly variable depending on their relative distance from the lesion epicenter and also among treated animals. Moreover, none of these neurons expressed subtype-specific molecular markers examined such as HB9, Islet1, Lim1, and Lim3 (Yamamoto et al., 2001b and references therein), and therefore whether they differentiated into specific neuronal subtypes remained undetermined.

The coadministration of BDNF with GFs neither increased the percentage of $\mathrm{GFP}^{+} / \mathrm{HuC} / \mathrm{D}^{+}$cells compared with $\mathrm{GF}$ treatment alone, nor induced $\mathrm{GFP}^{+} / \mathrm{NeuN}^{+}$cells in control virus-infected animals (no $\mathrm{GFP}^{+} / \mathrm{NeuN}^{+}$cells among $652 \mathrm{GFP}^{+}$cells examined). When combined with Ngn2 and GFs, however, BDNF significantly increased the percentage of $\mathrm{GFP}^{+} / \mathrm{NeuN}^{+}$cells among total $\mathrm{GFP}^{+}$cells $(28.2 \pm 3.4 \% ; n=3$ animals; $p<0.01$ compared with animals without BDNF treatment) (Fig. 7A). Concomitant with this increase, the percentage of $\mathrm{GFP}^{+} / \mathrm{GFAP}^{+}$ cells was significantly lower in both Ngn2/GF- and Ngn2/GF/ BDNF-treated animals compared with the control level (3.8 \pm 0.9 and $3.7 \pm 0.4 \%$ vs $6.3 \pm 0.5 \% ; p<0.01$ ) (Fig. $7 B$ ). This decrease alone, however, could not fully account for the much larger increase of $\mathrm{GFP}^{+} / \mathrm{NeuN}^{+}$cells, suggesting that $\mathrm{Ngn} 2$ and BDNF did not simply inhibit gliogenesis, but rather actively promoted generation of neurons.

We further followed the survival of $\mathrm{GFP}^{+} / \mathrm{NeuN}^{+}$cells in vivo. At DAI7, the estimated number of $\mathrm{GFP}^{+} / \mathrm{NeuN}^{+}$neurons was $5.4 \pm 0.5 \times 10^{3}(n=3)$ per spinal cord in Ngn2 virusinfected/GF-treated animals (Fig. 7C). Their numbers, however, were only 33 and $3 \%$ at DAI14 and DAI28, respectively, compared with that detected at DAI7. Although the total number of
$\mathrm{GFP}^{+}$cells decreased during this period (Fig. 7D), the percentage of $\mathrm{NeuN}^{+}$neurons among them also decreased over time (Fig. $7 A)$. Thus, $\mathrm{GFP}^{+} / \mathrm{NeuN}^{+}$new neurons appeared to be eliminated faster than other $\mathrm{GFP}^{+}$cell populations in injured tissue. Silencing of the GFP transgene could partly explain the observed loss of GFP-labeled new neurons (Vroemen et al., 2003). However, a higher percentage (33\%) of control virus-infected cells, in which the fraction of new neurons was much smaller, survived up to DAI28. Furthermore, we observed longer survival of Ngn2 virus-infected cells in other parts of the CNS (our unpublished results). Thus, we favor the idea that the observed decrease reflected the actual loss of new neurons in injured spinal cords. Consistent with this idea, when the neurotrophic factor BDNF, which is thought to promote survival of neurons, increased the number of $\mathrm{GFP}^{+} / \mathrm{NeuN}^{+}$cells 1.9 -fold in Ngn2/GF-treated animals at DAI7 $\left(9.4 \pm 0.2 \times 10^{3} ; n=4 ; p<0.001\right.$ in two-tailed unpaired $t$ test) (Fig. 7C). Moreover, larger numbers of $\mathrm{GFP}^{+} /$ $\mathrm{NeuN}^{+}$cells remained at DAI14 and DAI28 in BDNF-treated animals $(p<0.0001)$ (Fig. $7 C$ ). However, few $\mathrm{GFP}^{+} / \mathrm{NeuN}^{+}$ cells remained detectable at DAI56 or later time points (data not shown). Thus, the long-term survival of newly generated neurons appears to be very limited in the injured spinal cord.

\section{Stimulation of oligodendrogenesis by Mash1}

We next tested the effect of another proneural transcription factor, Mash1, which has been implicated in both neurogenesis and oligodendrogenesis during development (Parras et al., 2004). When NPCs were isolated as neurospheres from Mash1 virusesinfected tissue, significantly higher percentages of Mash1expressing cells differentiated into $\mathrm{O}_{4}{ }^{+}$and $\mathrm{GalC}^{+}$oligodendrocytes, and conversely, a much smaller fraction became $\mathrm{GFAP}^{+}$ astrocytes compared with control virus-infected cells (Fig. 8A). Unlike Ngn2, Mash1 did not change the percentage of TuJ1 ${ }^{+}$ neurons among $\mathrm{GFP}^{+}$cells. Thus, Mash1 selectively increased oligodendrocytes in culture of adult spinal cord NPCs.

As described above, a substantial fraction of control virusinfected cells were $\mathrm{GalC}^{+}$in vivo (Fig. 4I). These results are consistent with previous studies in which production of new oligodendrocytes by $\mathrm{NG}_{2}{ }^{+}$cells was detected under various insult conditions (McTigue et al., 1998, 2001; Ishii et al., 2001; Watanabe et al., 2002, 2004; Talbott et al., 2005; Zai and Wrathall, 2005; Yang et al., 2006). In line with this, we found that some $\mathrm{NG}^{+}$cells in injured tissue expressed endogenous Mash1 (Fig. $8 B$ ). This is in sharp contrast to endogenous Ngn2; we could not detect any cells expressing Ngn2 at any time point examined after injury (data not shown) (Yamamoto et al., 2001b). Such NG2 ${ }^{+} /$ Mash $1^{+}$cells, however, were small in number at DAI14, and almost disappeared at DAI28. These results raise the possibility that endogenous Mash1 is involved in the generation of new oligodendrocytes, but its limited expression accounts for their restricted generation and maturation in injured tissue.

To test this idea, we examined the effect of constitutive overexpression of Mash1 together with GF treatment in vivo. Consistent with the results of the above in vitro experiments, significantly larger fractions of Mash1 virus-infected cells became $\mathrm{GalC}^{+}$and GST- $\pi^{+}$oligodendrocytes compared with control virus-infected cells (Fig. 8C,F). Over one-third (38.9 $\pm 7.2 \%$; $n=$ 4 animals) of total Mash1-expressing cells were GST- $\pi^{+}$at DAI7 (Fig. $8 F$ ). Because few $\mathrm{GFP}^{+}$cells expressed these markers at DAI3, these results suggest that Mash1 stimulated the production of new oligodendrocytes in situ. Furthermore, at DAI28, a small but significant fraction of $\mathrm{GFP}^{+}$cells expressed RIP (Fig. 8D) and PLP (Fig. $8 E$ ), markers for more mature, myelin-forming 

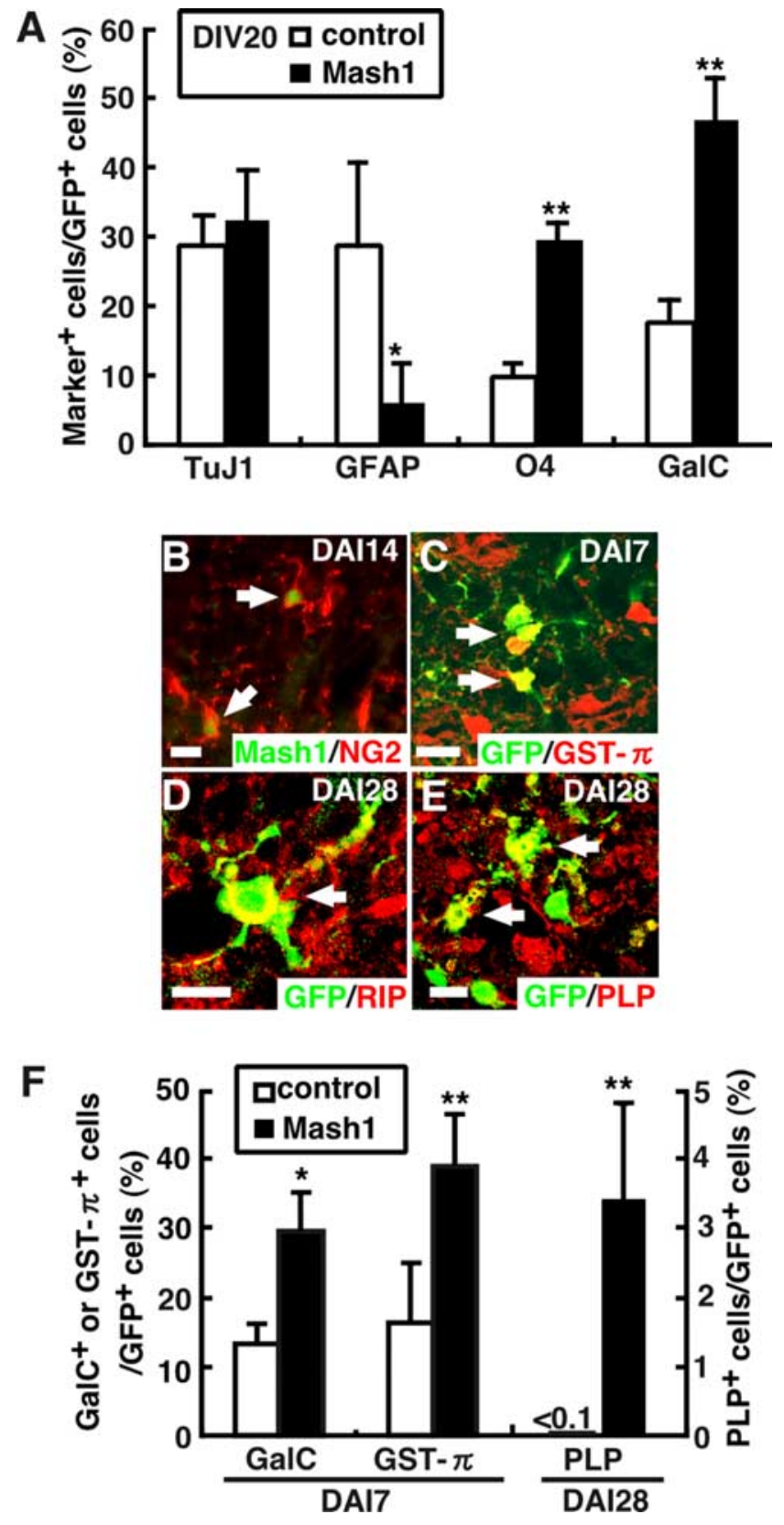

Figure 8. Stimulation of oligodendrocyte generation by Mash1. $\boldsymbol{A}$, Increased oligodendrocyte differentiation in Mash1-expressing neurosphere cells. Injured spinal cords infected with control (open bars) and Mash1 (filled bars) viruses were subjected to neurosphere culture at DAI3. Neurospheres formed at DIV14 were dissociated into single cells and induced to differentiate in monolayer for $6 \mathrm{~d}$. The percentages of GFP ${ }^{+}$cells expressing respective neuronal and glial cell markers were quantified (mean $\pm S D ; n=3-6$ animals; ${ }^{*} p<0.05 ;{ }^{* *} p<0.01$ compared with control virus-infected cells). $\boldsymbol{B}$, Expression of endogenous Mash1 (green) in $\mathrm{NG}^{+}{ }^{+}$cells (red, indicated by arrow) in vivo. $(-E$, Expression of the oligodendrocyte lineage cell markers GST- $\pi(\boldsymbol{C})$, RIP $(\boldsymbol{D})$, and PLP (E) (red) in Mash1 virus-infected, GFP ${ }^{+}$cells (green, indicated by arrows). $\boldsymbol{F}$, Stimulation of oligodendrocyte differentiation by Mash1. The percentages of GFP ${ }^{+}$cells expressing oligodendroglial markers in spinal cords infected with control (open bars) and Mash1 (filled bars) viruses were quantified at DAI7 or DAI28. GalC ${ }^{+}$cells were examined using dissociated single cells, whereas GST- $\pi^{+}$and PLP ${ }^{+}$cells were detected in tissue sections. Data are mean \pm SD $\left(n=3\right.$ animals; ${ }^{*} p<0.05$; ${ }^{* *} p<0.01$ compared with control virus-infected cells). Scale bars: $\boldsymbol{B}, \boldsymbol{E}, 20 \mu \mathrm{m} ; \boldsymbol{C}, \boldsymbol{D}, 10 \mu \mathrm{m}$.

cells, which were never detected in control virus-infected tissues (Fig. 8 F). We detected $4.8 \pm 0.7 \times 10^{4}$ and $1.5 \pm 0.4 \times 10^{4} \mathrm{GFP}^{+}$ cells at DAI7 and DAI28, respectively, in animals treated with Mash1 viruses and GFs. The estimated number of $\mathrm{GFP}^{+}$/
GST $-\pi^{+}$cells at DAI7 was, thus, $1.87 \times 10^{4}$ cells per spinal cord. Despite this relatively large number of immature cells detected early, only $2.7 \%$ of them appeared to advance to $\mathrm{PLP}^{+}$cells at DAI28 (510 $\mathrm{GFP}^{+} / \mathrm{PLP}^{+}$cells per spinal cord). Moreover, $\mathrm{GFP}^{+} / \mathrm{PLP}^{+}$and $\mathrm{GFP}^{+} / \mathrm{GST}-\pi^{+}$cells were barely detectable at DAI56 and later time points (data not shown). Instead, the majority (50.8 $\pm 6.3 \% ; n=3$ animals) of Mash1-expressing cells remained $\mathrm{NG}_{2}{ }^{+}$at DAI28. These results suggest that the major limiting step in regeneration of oligodendrocytes is the survival of immature cells and their maturation to myelin-forming cells.

\section{Discussion}

Spontaneous tissue regeneration after damage is very limited in the adult spinal cord. Many lines of recent studies have demonstrated that such limitation is attributable to, at least in part, restricted differentiation of endogenous NPCs in vivo (for review, see Q. Cao et al., 2002). In this study, we describe strategies to overcome such restriction.

\section{Retrovirus-mediated genetic manipulation of NPCs in situ}

We used GFP-expressing retroviruses to genetically manipulate proliferative cells in the injured spinal cord. We found that a fraction of virus-infected, $\mathrm{GFP}^{+}$cells grew as neurospheres and differentiated into neurons and glia in culture, demonstrating that they exhibited the properties of NPCs. Importantly, the majority $(>80 \%)$ of $\mathrm{GFP}^{+}$cells that formed neurospheres were Olig ${ }^{+}$and $\mathrm{Nkx} 2.2^{+}$, and $\sim 30 \%$ of them were also NG2 ${ }^{+}$. Cells expressing these markers were also the predominant cell type among the whole neurosphere-forming cells derived from the injured spinal cord.

$\mathrm{NG}_{2}{ }^{+}$cells in the adult CNS have originally been thought to be glia-restricted progenitors (Horner et al., 2000; Dawson et al., 2003). Previous studies, however, have revealed that a subpopulation of $\mathrm{NG}_{2}{ }^{+}$cells in the adult forebrain possesses the ability to produce neurons (Belachew et al., 2003; Nunes et al., 2003). $\mathrm{NG} 2{ }^{+}$cells are also the major proliferative cells in the adult spinal cord (Ishii et al., 2001; McTigue et al., 2001; Watanabe et al., 2002, 2004; Talbott et al., 2005). In particular, Horky et al. (2006) have demonstrated previously that NG ${ }^{+}$cells are the predominant cell type that divides early after injury. Other studies have shown that Olig ${ }^{+}$and $\mathrm{Nkx} 2.2^{+}$cells also comprise a significant fraction of proliferative cells, and that many of them coexpress NG2 (Yamamoto et al., 2001b; Watanabe et al., 2004; Talbott et al., 2005; Kitada and Rowitch, 2006). Consistent with these observations, GFP retroviruses administered immediately after injury preferentially infected Olig $2^{+} / \mathrm{Nkx} 2.2^{+} / \mathrm{NG} 2{ }^{+}$cells. Horky et al. (2006) also reported a similar result using a different virus construct and injury paradigm. Given the observation that a significant fraction of these cells differentiated into neurons or oligodendrocytes in GF-treated animals, these results suggest that they represent at least a part of endogenous NPCs in the adult spinal cord. We found, however, that only $\sim 40 \%$ of $\mathrm{NG}^{+}$cells coexpressed Olig2 and Nkx2.2 in injured tissue. Likewise, Olig2 ${ }^{+}$ and Nkx2.2 ${ }^{+}$cells contain both NG2 ${ }^{+}$and NG2 ${ }^{-}$cell populations (Watanabe et al., 2004; Talbott et al., 2005). Thus, cells expressing these markers are heterogeneous, and neither of them appears to be specific for NPCs. Moreover, although the vast majority of $\mathrm{GFP}^{+}$cells were Olig $2^{+} / \mathrm{Nkx} 2.2^{+} / \mathrm{NG} 2{ }^{+}$in vivo, not all of these cells formed neurospheres in vitro. This could be because NPCs are only a fraction among cells expressing these markers, or alternatively, because currently available culture conditions do not support proliferation of all NPCs in vitro. More 
studies are necessary to define the in vivo identity of NPCs in the adult spinal cord.

\section{Overcoming environmental restriction by growth factors and genetic manipulations}

Differentiation of NPCs into neurons and oligodendrocytes is tightly restricted by the environment in the injured spinal cord. Then, how do the manipulations described in this study overcome such restriction? First, it is unlikely that otherwise nonNPC cells transdifferentiated into NPC-like cells in response to exogenous manipulations. The molecular properties of the major fraction of $\mathrm{GFP}^{+}$cells early after infection were essentially identical between manipulated and unmanipulated tissues, and moreover, such phenotypes were preserved in $\mathrm{GFP}^{+}$cellsderived neurospheres. Thus, pre-existing, endogenous NPCs were likely responsible for generating new neurons and oligodendrocytes in vivo.

Previous studies reported various beneficial actions of GFs in spinal cord injury (Cheng et al., 1996; Lee et al., 1999; Teng et al., 1999; Rabchevsky et al., 2000; Kojima and Tator, 2002; Meijs et al., 2004). Their effects on neurogenesis by endogenous NPCs, however, have not yet been documented. We have demonstrated that direct administration of GFs into injured tissue can induce the production of new neurons in the otherwise non-neurogenic spinal cord. GFs increased the number of total GFP ${ }^{+}$cells in situ. GFs also increased the number of $\mathrm{GFP}^{+} / \mathrm{TuJ} 1^{+}$new neurons between DAI3 and DAI7. These results are consistent with the idea that GFs stimulated both proliferation and neuronal differentiation of endogenous NPCs. GFs might have enhanced survival of NPCs and newborn neurons as well. GFs act as mitogens for NPCs in vitro (Weiss et al., 1996; Kojima and Tator, 2002; Martens et al., 2002) and, thus, are generally thought to be inhibitory for their differentiation. Therefore, their neuron-inducing action in vivo is apparently puzzling. However, multiple extracellular molecules likely act simultaneously on NPCs in vivo so that the outcome of their combinatorial actions could be different from that observed in vitro. In fact, previous studies have shown that exogenous GFs can enhance neurogenesis after brain injury (Nakatomi et al., 2002; Teramoto et al., 2003). Our data, together with other previous studies, suggest that the induction of new neurons by GFs could be through interactions with multiple signaling pathways such as those for Notch, BMPs, and CNTF (Yamamoto et al., 2001b; Chojnacki et al., 2003; Mikami et al., 2004; Setoguchi et al., 2004). In this context, GFs could either directly act on NPCs, or indirectly modulate their activities through acting on other cell types such as inflammatory cells (Schwab, 2002; Hauben and Schwartz, 2003; Mikami et al., 2004; Yang et al., 2006). How GFs stimulate neurogenesis in the complex environment of injured tissue remains to be clarified.

Our data suggest that maturation is another limiting step in neuronal cell replacement in the injured spinal cord. Although a significant fraction of $\mathrm{GFP}^{+}$cells became $\mathrm{HuC} / \mathrm{D}^{+}$cells in GFtreated animals, few cells were found to express NeuN that features a more mature phenotype of neurons. Although the mechanisms underlying this inhibition are currently unknown, we found that overexpression of Ngn2 can overcome this limiting step. Although Ngn2 alone strongly stimulated neurogenesis by NPCs in vitro, its effect on the production of $\mathrm{HuC} / \mathrm{D}^{+}$immature neurons in vivo was rather weak in the absence of GFs. However, even without GFs, a small, but significant number of Ngn2expressing cells became $\mathrm{NeuN}^{+}$. Moreover, when combined with GFs, Ngn2 dramatically increased the number of $\mathrm{GFP}^{+} / \mathrm{NeuN}^{+}$ cells. Thus, the action of Ngn2 appeared to be distinct from that of GFs, and their combination was most effective in inducing neurogenesis in vivo.

In contrast, differentiation of $\mathrm{GFP}^{+}$cells into $\mathrm{GalC}^{+}$/ GST- $\pi^{+}$immature oligodendrocytes was detectable even in GFuntreated animals. Yet, their maturation to $\mathrm{MBP}^{+} / \mathrm{PLP}^{+}$ myelin-forming cells did not occur at a detectable level. We showed that overexpression of Mash1 can enhance the production of $\mathrm{GalC}^{+} / \mathrm{GST}-\pi^{+}$cells, and that at least some of these cells proceed to more mature $\mathrm{PLP}^{+}$oligodendrocytes. These results suggest that like neuronal cells, maturation and survival is a crucial step in replacement of oligodendrocytes in the injured spinal cord. This could be attributable to the absence of appropriate trophic support and/or the presence of cell death-inducing signals (Nakamura and Bregman, 2001; Velardo et al., 2004). Thus, a possible means to promote survival of new neurons and oligodendrocytes could be a sustained supply of neurotrophic factors and/or antagonists for cell death signals (McTigue et al., 1998; Lee et al., 1999; Liu et al., 1999; Namiki et al., 2000; Rabchevsky et al., 2000; Coumans et al., 2001; Meijs et al., 2004; Cao et al., 2005). Moreover, integration into the circuitry is probably important for their maturation and survival in vivo (Dobkin and Havton, 2004). Thus, strategies to enhance regeneration of these cells locally may need to be coordinated with those for reconstruction of long-range axonal tracts (Schwab, 2002; Silver and Miller, 2004).

\section{Cell replacement strategies for spinal cord injury}

In this study, we detected $\sim 9400 \mathrm{NeuN}^{+}$new neurons in Ngn2 virus/GF-treated animals. This level of neuronal cell replacement by endogenous NPCs is comparable with those reported for other parts of the CNS (Arvidsson et al., 2002; Nakatomi et al., 2002; Teramoto et al., 2003; Chmielnicki et al., 2004), and also to those achieved by grafting exogenous cells (Chow et al., 2000; Q. L. Cao et al., 2001, 2002; Hofstetter et al., 2005). Considering that our retrovirus-mediated method labeled only a small fraction of NPCs within tissue, the maximum neurogenic capacity of endogenous NPCs is likely larger than this level. However, poor longterm survival of new neurons is still the major issue common to the strategies using endogenous and exogenous NPCs. Thus, in terms of functional recovery, significance of supplying new neurons at this level of quantity remains to be explored. In case of transplantation of exogenous NPCs, many cell types other than neurons are supplied to lesions, which, as a whole, exert beneficial effects (Lu et al., 2003; Hofstetter et al., 2005). Under certain circumstances, grafted cells appear to exert detrimental effects as well (Enzmann et al., 2005; Hofstetter et al., 2005). Similar situations may also need to be considered in case of mobilizing endogenous NPCs by growth factor treatment and genetic manipulations. Additional improvement of such strategies may lead to development of novel cell replacement therapy for spinal cord injury.

\section{References}

Alvarez-Dolado M, Pardal R, Garcia-Verdugo JM, Fike JR, Lee HO, Pfeffer K, Lois C, Morrison SJ, Alvarez-Buylla A (2003) Fusion of bone-marrowderived cells with Purkinje neurons, cardiomyocytes and hepatocytes. Nature 425:968-973.

Arvidsson A, Collin T, Kirik D, Kokaia Z, Lindvall O (2002) Neuronal replacement from endogenous precursors in the adult brain after stroke. Nat Med 8:963-970.

Belachew S, Chittajallu R, Aguirre AA, Yuan X, Kirby M, Anderson S, Gallo V (2003) Postnatal NG2 proteoglycan-expressing progenitor cells are intrinsically multipotent and generate functional neurons. J Cell Biol 161:169-186.

Cao Q, Benton RL, Whittemore SR (2002) Stem cell repair of central nervous system injury. J Neurosci Res 68:501-510. 
Cao Q, Xu XM, DeVries WH, Enzmann GU, Ping P, Tsoulfas P, Wood PM, Bunge MB, Whittemore SR (2005) Functional recovery in traumatic spinal cord injury after transplantation of multineurotrophin-expressing glial-restricted precursor cells. J Neurosci 25:6947-6957.

Cao QL, Zhang YP, Howard RM, Walters WM, Tsoulfas P, Whittemore SR (2001) Pluripotent stem cells engrafted into the normal or lesioned adult rat spinal cord are restricted to a glial lineage. Exp Neurol 167:48 -58.

Cao QL, Howard RM, Dennison JB, Whittemore SR (2002) Differentiation of engrafted neuronal-restricted precursor cells is inhibited in the traumatically injured spinal cord. Exp Neurol 177:349-359.

Chen J, Leong SY, Schachner M (2005) Differential expression of cell fate determinants in neurons and glial cells of adult mouse spinal cord after compression injury. Eur J Neurosci 22:1895-1906.

Cheng H, Cao Y, Olson L (1996) Spinal cord repair in adult paraplegic rats: partial restoration of hind limb function. Science 273:510-513.

Chmielnicki E, Benraiss A, Economides AN, Goldman SA (2004) Adenovirally expressed noggin and brain-derived neurotrophic factor cooperate to induce new medium spiny neurons from resident progenitor cells in the adult striatal ventricular zone. J Neurosci 24:2133-2142.

Chojnacki A, Shimazaki T, Gregg C, Weinmaster G, Samuel Weiss S (2003) Glycoprotein 130 signaling regulates notch1 expression and activation in the self-renewal of mammalian forebrain neural stem cells. J Neurosci 23:1730-1741.

Chow SY, Moul J, Tobias CA, Himes BT, Liu Y, Obrocka M, Hodge L, Tessler A, Fischer I (2000) Characterization and intraspinal grafting of EGF/ bFGF-dependent neurospheres derived from embryonic rat spinal cord. Brain Res 874:87-106.

Coumans JV, Lin TT, Dai HN, MacArthur L, McAtee M, Nash C, Bregman BS (2001) Axonal regeneration and functional recovery after complete spinal cord transection in rats by delayed treatment with transplants and neurotrophins. J Neurosci 21:9334-9344.

Dawson MR, Polito A, Levine JM, Reynolds R (2003) NG2-expressing glial progenitor cells: an abundant and widespread population of cycling cells in the adult rat CNS. Mol Cell Neurosci 24:476-488.

Dobkin BH, Havton LA (2004) Basic advances and new avenues in therapy of spinal cord injury. Annu Rev Med 55:255-282.

Enzmann GU, Benton RL, Woock JP, Howard RM, Tsoulfas P, Whittemore SR (2005) Consequences of noggin expression by neural stem, glial, and neuronal precursor cells engrafted into the injured spinal cord. Exp Neurol 195:293-304.

Goldman SA (2004) Directed mobilization of endogenous neural progenitor cells: the intersection of stem cell biology and gene therapy. Curr Opin Mol Ther 6:466-472.

Han SS, Kang DY, Mujtaba T, Rao MS, Fischer I (2002) Grafted lineagerestricted precursors differentiate exclusively into neurons in the adult spinal cord. Exp Neurol 177:360-375.

Han SS, Liu Y, Tyler-Polsz C, Rao MS, Fischer I (2004) Transplantation of glial-restricted precursor cells into the adult spinal cord: survival, glialspecific differentiation, and preferential migration in white matter. Glia 45:1-16.

Hauben E, Schwartz M (2003) Therapeutic vaccination for spinal cord injury: helping the body to cure itself. Trends Pharmacol Sci 24:7-12.

Hill CE, Proschel C, Noble M, Mayer-Proschel M, Gensel JC, Beattie MS, Bresnahan JC (2004) Acute transplantation of glial-restricted precursor cells into spinal cord contusion injuries: survival, differentiation, and effects on lesion environment and axonal regeneration. Exp Neurol 190:289-310.

Hofstetter CP, Holmstrom NA, Lilja JA, Schweinhardt P, Hao J, Spenger C, Wiesenfeld-Hallin Z, Kurpad SN, Frisen J, Olson L (2005) Allodynia limits the usefulness of intraspinal neural stem cell grafts; directed differentiation improves outcome. Nat Neurosci 8:346-353.

Horky LL, Galimi F, Gage FH, Horner PJ (2006) Fate of endogenous stem/ progenitor cells following spinal cord injury. J Comp Neurol 498:525-538.

Horner PJ, Gage FH (2000) Regenerating the damaged central nervous system. Nature 407:963-970.

Horner PJ, Power AE, Kempermann G, Kuhn HG, Palmer TD, Winkler J, Thal LJ, Gage FH (2000) Proliferation and differentiation of progenitor cells throughout the intact adult rat spinal cord. J Neurosci 20:2218-2228.

Ishii K, Toda M, Nakai Y, Asou H, Watanabe M, Nakamura M, Yato Y, Fujimura Y, Kawakami Y, Toyama Y, Uyemura K (2001) Increase of oligodendrocyte progenitor cells after spinal cord injury. J Neurosci Res 65:500-507.

Johansson CB, Momma S, Clarke DL, Risling M, Lendahl U, Frisen J (1999) Identification of a neural stem cell in the adult mammalian central nervous system. Cell 96:25-34.

Kamakura S, Oishi K, Yoshimatsu T, Nakafuku M, Masuyama N, Gotoh Y (2004) Hes binding to STAT3 mediates crosstalk between Notch and JAK-STAT signalling. Nat Cell Biol 6:547-554.

Kitada M, Rowitch DH (2006) Transcription factor co-expression patterns indicate heterogeneity of oligodendroglial subpopulations in the adult spinal cord. Glia 54:35-46.

Kojima A, Tator CH (2002) Intrathecal administration of epidermal growth factor and fibroblast growth factor 2 promotes ependymal proliferation and functional recovery after spinal cord injury in adult rats. J Neurotrauma 19:223-238.

Leber SM, Sanes JR (1991) Lineage analysis with a recombinant retrovirus: application to chick spinal motor neurons. Adv Neurol 56:27-36.

Lee TT, Green BA, Dietrich WD, Yezierski RP (1999) Neuroprotective effects of basic fibroblast growth factor following spinal cord contusion injury in the rat. J Neurotrauma 16:347-356.

Lim DA, Tramontin AD, Trevejo JM, Herrera DG, Garcia-Verdugo JM, Alvarez-Buylla A (2000) Noggin antagonizes BMP signaling to create a niche for adult neurogenesis. Neuron 28:713-726.

Liu Y, Kim D, Himes BT, Chow SY, Schallert T, Murray M, Tessler A, Fischer I (1999) Transplants of fibroblasts genetically modified to express BDNF promote regeneration of adult rat rubrospinal axons and recovery of forelimb function. J Neurosci 19:4370-4387.

Lu P, Jones LL, Snyder EY, Tuszynski MH (2003) Neural stem cells constitutively secrete neurotrophic factors and promote extensive host axonal growth after spinal cord injury. Exp Neurol 181:115-129.

Martens DJ, Seaberg RM, van der Kooy D (2002) In vivo infusions of exogenous growth factors into the fourth ventricle of the adult mouse brain increase the proliferation of neural progenitors around the fourth ventricle and the central canal of the spinal cord. Eur J Neurosci 16:1045-1057.

McTigue DM, Horner PJ, Stokes BT, Gage FH (1998) Neurotrophin-3 and brain-derived neurotrophic factor induce oligodendrocyte proliferation and myelination of regenerating axons in the contused adult rat spinal cord. J Neurosci 18:5354-5365.

McTigue DM, Wei P, Stokes BT (2001) Proliferation of NG2-positive cells and altered oligodendrocyte numbers in the contused rat spinal cord. J Neurosci 21:3392-3400.

Meijs MF, Timmers L, Pearse DD, Tresco PA, Bates ML, Joosten EA, Bunge MB, Oudega M (2004) Basic fibroblast growth factor promotes neuronal survival but not behavioral recovery in the transected and Schwann cell implanted rat thoracic spinal cord. J Neurotrauma 21:1415-1430.

Mikami Y, Okano H, Sakaguchi M, Nakamura M, Shimazaki T, Okano HJ, Kawakami Y, Toyama Y, Toda M (2004) Implantation of dendritic cells in injured adult spinal cord results in activation of endogenous neural stem/progenitor cells leading to de novo neurogenesis and functional recovery. J Neurosci Res 76:453-465.

Mocchetti I, Rabin SJ, Colangelo AM, Whittemore SR, Wrathall JR (1996) Increased basic fibroblast growth factor expression following contusive spinal cord injury. Exp Neurol 141:154-164.

Morita S, Kojima T, Kitamura T (2000) Plat-E: an efficient and stable system for transient packaging of retroviruses. Gene Ther 7:1063-1066.

Nakamura M, Bregman BS (2001) Differences in neurotrophic factor gene expression profiles between neonate and adult rat spinal cord after injury. Exp Neurol 169:407-415.

Nakashima K, Takizawa T, Ochiai W, Yanagisawa M, Hisatsune T, Nakafuku M, Miyazono K, Kishimoto T, Kageyama R, Taga T (2001) BMP2mediated alteration in the developmental pathway of fetal mouse brain cells from neurogenesis to astrocytogenesis. Proc Natl Acad Sci USA 98:5868-5873.

Nakatomi H, Kuriu T, Okabe S, Yamamoto S, Hatano O, Kawahara N, Tamura A, Kirino T, Nakafuku M (2002) Regeneration of hippocampal pyramidal neurons after ischemic brain injury by recruitment of endogenous neural progenitors. Cell 110:429-441.

Namiki J, Kojima A, Tator CH (2000) Effect of brain-derived neurotrophic factor, nerve growth factor, and neurotrophin-3 on functional recovery and regeneration after spinal cord injury in adult rats. J Neurotrauma 17:1219-1231.

Nunes MC, Roy NS, Keyoung HM, Goodman RR, McKhann G II, Jiang L, 
Kang J, Nedergaard M, Goldman SA (2003) Identification and isolation of multipotential neural progenitor cells from the subcortical white matter of the adult human brain. Nat Med 9:439-447.

Parras CM, Galli R, Britz O, Soares S, Galichet C, Battiste J, Johson JE, Nakafuku M, Vescovi A, Guillemot F (2004) Mash1 specifies neurons and oligodendrocytes in the postnatal brain. EMBO J 23:4495-4505.

Rabchevsky AG, Fugaccia I, Turner AF, Blades DA, Mattson MP, Scheff SW (2000) Basic fibroblast growth factor (bFGF) enhances functional recovery following severe spinal cord injury to the rat. Exp Neurol 164:280-291.

Schwab ME (2002) Repairing the injured spinal cord. Science 295:1029-1031.

Setoguchi T, Yone K, Matsuoka E, Takenouchi H, Nakashima K, Sakou T, Komiya S, Izumo S (2001) Traumatic injury-induced BMP7 expression in the adult rat spinal cord. Brain Res 921:219-225.

Setoguchi T, Nakashima K, Takizawa T, Yanagisawa M, Ochiai W, Okabe M, Yone K, Komiya S, Taga T (2004) Treatment of spinal cord injury by transplantation of fetal neural precursor cells engineered to express BMP inhibitor. Exp Neurol 189:33-44.

Shihabuddin LS, Horner PJ, Ray J, Gage FH (2000) Adult spinal cord stem cells generate neurons after transplantation in the adult dentate gyrus. J Neurosci 20:8727-8735.

Silver J, Miller JH (2004) Regeneration beyond the glial scar. Nat Rev Neurosci 5:146-156.

Sun Y, Nadal-Vicens M, Misono S, Lin MZ, Zubiaga A, Hua X, Fan G, Greenberg ME (2001) Neurogenin promotes neurogenesis and inhibits glial differentiation by independent mechanisms. Cell 104:365-376.

Talbott JF, Loy DN, Liu Y, Qiu MS, Bunge MB, Rao MS, Whittemore SR (2005) Endogenous Nkx2.2+/Olig2+ oligodendrocyte precursor cells fail to remyelinate the demyelinated adult rat spinal cord in the absence of astrocytes. Exp Neurol 192:11-24.

Teng YD, Mocchetti I, Taveira-DaSilva AM, Gillis RA, Wrathall JR (1999) Basic fibroblast growth factor increases long-term survival of spinal motor neurons and improves respiratory function after experimental spinal cord injury. J Neurosci 19:7037-7047.

Teramoto T, Qiu J, Plumier JC, Moskowitz MA (2003) EGF amplifies the replacement of parvalbumin-expressing striatal interneurons after ischemia. J Clin Invest 111:1125-1132.

Torii M, Matsuzaki F, Osumi N, Kaibuchi K, Nakamura S, Casarosa S, Guillemot F, Nakafuku M (1999) Transcription factors Mash-1 and Prox-1 delineate early steps in differentiation of neural stem cells in the developing central nervous system. Development 126:443-456.

Velardo MJ, Burger C, Williams PR, Baker HV, Lopez MC, Mareci TH, White TE, Muzyczka N, Reier PJ (2004) Patterns of gene expression reveal a temporally orchestrated wound healing response in the injured spinal cord. J Neurosci 24:8562-8576.

Vroemen M, Aigner L, Winkler J, Weidner N (2003) Adult neural progenitor cell grafts survive after acute spinal cord injury and integrate along axonal pathways. Eur J Neurosci 18:743-751.

Watanabe M, Toyama Y, Nishiyama A (2002) Differentiation of proliferated NG2-positive glial progenitor cells in a remyelinating lesion. J Neurosci Res 69:826-836.

Watanabe M, Hadzic T, Nishiyama A (2004) Transient upregulation of Nkx2.2 expression in oligodendrocyte lineage cells during remyelination. Glia 46:311-322.

Weiss S, Dunne C, Hewson J, Wohl C, Wheatley M, Peterson AC, Reynolds BA (1996) Multipotent CNS stem cells are present in the adult mammalian spinal cord and ventricular neuroaxis. J Neurosci 16:7599-7609.

Yamamoto S, Yamamoto N, Kitamura T, Nakamura K, Nakafuku M (2001a) Proliferation of parenchymal neural progenitors in response to injury in the adult rat spinal cord. Exp Neurol 172:115-127.

Yamamoto S, Nagao M, Sugimori M, Kosako H, Nakatomi H, Yamamoto N, Takebayashi H, Nabeshima Y, Kitamura T, Weinmaster G, Nakamura K, Nakafuku M (2001b) Transcription factor expression and Notchdependent regulation of neural progenitors in the adult rat spinal cord. J Neurosci 21:9814-9823.

Yang H, Lu P, McKay HM, Bernot T, Keirstead H, Steward O, Gage FH, Edgerton VR, Tuszynski MH (2006) Endogenous neurogenesis replaces oligodendrocytes and astrocytes after primate spinal cord injury. J Neurosci 26:2157-2166.

Zai LJ, Wrathall JR (2005) Cell proliferation and replacement following contusive spinal cord injury. Glia 50:247-257. 